Euskal ikerketen aldizkaria | Revue d'études basques |

Revista de estudios vascos | Basque studies review

Numéro spécial 3 | 2015

Euskal hizkera eta dialektoak gaur egun

\title{
Nola erabili onomastikaren ekarpenak dialektologia ikerketetan
}

\section{Patxi Salaberri}

\section{(2) OpenEdition \\ Journals}

Édition électronique

URL : http://journals.openedition.org/lapurdum/2675

DOI : 10.4000/lapurdum.2675

ISSN : 1965-0655

\section{Éditeur}

IKER

\section{Édition imprimée}

Date de publication : 1 novembre 2015

Pagination : 237-271

ISBN : 9782955341322

ISSN : $1273-3830$

Référence électronique

Patxi Salaberri, « Nola erabili onomastikaren ekarpenak dialektologia ikerketetan », Lapurdum [Linean] Numéro spécial 3 | 2015, Sarean emana----an 12 juillet 2017, kontsultatu 02 mai 2019. URL : http:// journals.openedition.org/lapurdum/2675; DOI : 10.4000/lapurdum.2675 


\title{
Nola erabili onomastikaren
}

\section{ekarpenak dialektologia ikerketetan}

\author{
Patxi SALABERRI
}

NUP - Euskaltzaindia

\section{Laburpena}

Lan honetan leku izenek dialektologiari egin diezazkioketen ekarpenak aipatzen ditugu, onomastika lanari ekiteko izan genuen motibazioa azaldu ondoren. Hasteko, herri izenetan aurkitzen ditugun atzizki eta bukaerek duten garrantziaz mintzo gara, toponimo horiek sortu zirenean bertan zeuden jende mugimenduen, izen moden eta joeren berri ematen digutelako, hein batean behintzat. Gero, orain arte egindako toponimia lanetan oinarriturik, zenbait alderditako euskara galduaren berri batzuk ematen ditugu, garbi aitortuz, hala ere, onomastika azterketen ekarpenek muga estuak dituztela. Ondoren, toponimoen generikoetan (-ko, -ra eta -ren-en ondoan agertzen diren izen arruntetan) dugun altxor aztertugabea nabarmentzen dugu eta, azkenik, artxibategietan datu bila gabiltzanean ateratzen zaizkigun zenbait hitz interesgarri aipatzen ditugu.

\section{Sarrera}

Onomastika, izenak aztertzen dituen jakitea, beregaina da egun, eta hein batean baizik ez dago hizkuntzalaritzarekin lotua. Bestelako estekak baditu, bistan da, izenak zein ikuspuntutatik aztertu nahi ditugun. Konparaziorako, sozionomastikak izenek gizartean duten jokabidearen berri ematen digu, eta literatura-onomastika izenek literaturan duten rolaz mintzo zaigu, pertsonaien deizioez, zer izen diren eta egileak haiekin zer erdietsi nahi duen, gehienetan helburu jakin batekin hautatu edo asmatuak izaten dira eta. Liburu bateko izendatze multzoak izendegi orokorrarekin zer-nolako harremanak dituen iker daiteke, eta ikertu ere ikertzen da. Badira, onomastikaren barnean, aztergaitako literatura onomastika besterik ez 
duten batzarrak, adar honek hondarreko urteotan hartu duen indarraren erakusgarri. Onoma aldizkariaren azken zenbakiak, bestalde, Name and law du gaitzat, izenek eta legeak ere lotura hertsia baitute.

Hiri edo auzo bateko tabernek zer izen duten, zeri zor zaizkion eta azken aldian horien izendabideetan alda-joerarik izan den ere azter daiteke. Nire irudipen hutsa dateke beharbada, baina erranen nuke Iruñean orain irekitzen diren taberna berriek -eta franko dira, krisiarekinoro har erdal izenak dituztela, ingelesetikakoak gehienbat, Bidezarra edo Kiliki-ren moduko batzuk alde bat uzten baditugu. Honelako lan gutxi daude gure artean (ikus Libano 2000, eta Santano 2000).

Nolahiko gisan, onomastikaren azterketari ekin nionean ez nintzen aipatu ditudan gauza horietan pentsatzen ari, horretarako gai ez nintzelako hain segur. Tesia egin beharrean suertatu nintzelarik motibatzen ninduen zerbait aukeratu nuen, ez lehenbizian, joskera gai niretako aski lehor batekin hasi nintzelako, baina bai ondoren, aitzina egin nahi banuen bihotza ukitzen zidan aztergaia hautatu behar nuela ikusi nuenean.

Gai hori gure herriaren euskalduntasun galdua zen: etxean makina bat aldiz adituak nituen Uxueko aurkintzen izenak, guk ardantzeak genituenak (Busa, Lakilazaba, Mugazuria, Rusiana, Zapaiz), ardantzeetatik hurbil zeudenak (Aurino, el paso Pistalorra), herriari hurran zirenak (el rincón de Zonbolozoko, la Aldabea de Anzandieta, la Aldabea de Turtunbera, Larziaga, Ollatu, Satea, Txorria), edo arrazoi batengatik edo bestearengatik uxuotarron ahotan maiz azaltzen direnak edo zirenak (Aldamara, Andiaga, Ardui, Astuziaga, Laku, Lakumulatu, Pipiratu, Mantxintxurreta, Redondiaga...).

Hauek guztiak eta beste anitz behin eta berriz adituak nituen haur denboran, eta guztiz ulergaitzak, ilunak, ziren niretako eta nire inguruan erabiltzen zituzten beste uxuetarrendako. Haiek bazekiten euskal izenak zirela, «aqui en tiempos se habló vasco» erraten zuten nire jendaki eta ezagun haiek, nahiz berek beren burua vasco-tzat ez izan, Nafarroan vasco denbora hartan 'euskalduna' zelako, hots, euskaraz bazekiena, arruntean hizkuntza nagusi izan eta gaztelaniaz nola edo hala baizik moldatzen ez zena. Oraino gogoan dut gurasoek kontatzen zutena: gerla garaian frontetik Uxuera «atseden» hartzera etorri ziren soldaduetan ba omen zen basaburutar bat, Udabekoa oker ez banaiz, pobratxo! gure amaren hitzetan, gaixoa! alegia, euskaraz besterik jakin ez eta besteekin -gehienak erdaldunak izaki eta- ezin mintza zitekeena.

Izen horiek eta oraindik hurbilago nituen nire deiturek zer erran nahi zuten ikasi nahiak motibatzen ninduen, nondik atera ziren, denboraz nolako itxura zuten jakin nahi nuen, aitak behin eta berriz aipatzen zuen ermitako Andre Mariaren irudian zegoen (eta dagoen) Abeaga idazkuna zer arraio zen, zergatik zuen, honek ere, -aga bukaeran, Aliaga, Andiaga, Astuziaga, Larziaga eta Redondiaga-k bezala, zer ikusteko zuten Laku-ko harri zaharrean ageri zen Lacubegi idazkun ezagun behiburudunak eta herri ondoko zoko baten izena den Lakubeli-k, zer ote zen Laku-ren aiekako Lakumulatu, eta abar.

Horiek guztiek motibatzen ninduten, bihotz ematen zidaten galderak egiten jarraitzeko. Garbi nuen euskal izenak zirela, ilunak baina euskal izenak, eta orduko euskara 
ikasia bainuen, izen haiei sorrera eman zien hizkera nolakoa zen jakin nahi nuen, Elkanoko Lizarragaren lanetan (orduan ezagutzen genituenetan) ageri zen euskara bera edo irudia zenetz. Bonaparteren mapa famatuan ageri zen hegoaldeko goi nafarreran kokatua izan behar zuen, bai, baina horretarako frogak behar nituen, zantzuak baino gehiago, eta horregatik lotu nintzen onomastika aztertzeari.

Banekien prozesu luzea izanen zela. Ekin eta ekin, urteak igaro nituen protokolo artxibategia zeritzanean, Donibane auzoan Agoizko tabernatik hurbil zen hartan, hasieran izugarrizko ilusioarekin, izen berriak ateratzen zirelako, eta nirekin era batera edo bestera lotura zuten gauzak aurkitzen nituelako: Salaberri deitura lehen aldiz 1629an kausitu nuen Uxuen, nire zazpigarren deitura den Abaurre Aezkoako herritik etorritako jendeari zor zitzaiola ikasi nuen, gure ardantzeetako bat zegoen dermioari behiala Lakilazaba ez, baizik Akirazabal edo Akirazabala zeritzala ikusi nuen, egungo aldaera itxuragabetua zegoela, eta aipatu Akirazabal horrek etxe aitzinean, azpian Zonbolozoko duen Aguilar gainarekin nolabaiteko lotura izan zezakeela sumatu nuen orduan.

Egia erran, orain uste dut artxibategian denbora gehiegi eman nuela eta beste alderdia, dialektologiaren inguruko teorizazioarekin zerikusia zuena, neurri batez alde batera utzi nuela. Ni ere aski teoria-zekena izan bainaiz nire denboran, datu ehiztari on xamarra apika, baina teorialari kaskarra.

Tesian, beraz, datu franko bai, baina datu horietatik ateratako etekin gutxi dago, behin dialektologialari eta teorialari hauta den Iñaki Caminok, arrazoi handiz noski, idatzi zuen bezala. Iñakik, uste dut, afera dialektologiaren ikuspuntutik zekusan, ez onomastikarenetik, menturaz ohartu gabe honetan hartan garrantzirik ez duten gauzek, ardura, munta handia izaten dutela: leku izen baten, deitura baten edo, oro har, onimo baten bilakaera zehatzak, egiturak (dokumentazioan behin ageri zaigun Orbaibar-ek, demagun, Erroibar eta Olloibar-en egitura berbera du), maiztasunak (unus testis-en bakardade latza), izendatzen duen eremuaren hedadurak eta bestek. Izenak berak ongi biltzea eta mapan zein bere lekuan zehatz ezartzea onomastikari bai, baina dialektologiari asko axola ez zaion eginkizuna da.

Eta hainbeste denbora eta lan eskainitako tesian garbitan gauza handirik atera ez banuen, ezin espero zitekeen bestelakoetan, geroagokoetan emaitzak anitzez hobeak izatea. Onomastikari guztiek (multxo bat besterik ez izanik ere) dakigu hau: toki izenek arlo batzuetan baizik ez digute dialektologiarako erabilgarri izan daitekeen informazio txukun zerbait ematen, hiztegiarenean, morfologiaren eremuren batean (atzizkienean, deklinabide atzizki zenbait ere barne), joskeran zerbaixka (esaldi toponimoak), fonologian arrasto batzuk..., baina, jakina, paradigmarik ezin osatu, polimorfismorik ez bilatu, hitz-ordenaz ahaztu, esaera eta esamoldeak ez ditu ikertzaileak inon ere opatuko, testurik eta maiz euskaldunik ere ez izanez... Mitxelenak (1985: 602) hau garbi zekusan: «La escasez del material, igual a cero para muchas zonas por lo que toca a textos, nos obliga a sacar el mayor partido posible de fuentes de otro carácter, así los onomásticos, que alguna falta pueden suplir» (beltza gurea da).

Hizkeren alderdi kronologikoa ere alde bat utzi behar da, sinkronia hutsa bederik, onomastika aztertzen dugunean, txukun egin nahi badugu, oraingo izenen azterketa gainditu 
eta dokumentaziora jo behar dugulako, eta hau zenbat eta zaharrago izan hainbat hobeki, nahiz geroagoko datuak ere ezin utzizkoak izan. Hots, ahal den aldaerarik zaharrena xerkatu behar da, eta gero haren ondokoak, egungo(eta)ra iritsi arte, izena oraino bizirik badago, bilakaera ikusi eta onimoa behar bezala aztertzeko eta arautzeko, izenek eskuarki, bai dokumentazioan eta bai (baina ez beti) ahozko erabileran, aldaera bat baino gehiago erakusten baitituzte, eta praktikotasunez bakarra aukeratu behar baita, delako onimoa ongienik islatzen duena hain zuzen. Eta honetarako, bistan da, arautze irizpideak behar dira, zenbait aldiz eztabaida iturri izan daitezkeenak, baina, nolanahi ere, baitezpadakoak direnak.

\section{Toponimia eta dialektologia}

\section{Atzizki banaketa eta euskalki banaketa, handi-handika}

Euskal dialektologian, eta euskalaritzan oro har, garrantzi handikoa izan da beti euskalkien banaketa. Hizkera bakoitza zein euskalkitan sartzen zen aztertzen zen lehen ere, baina irizpide gutxi xamarrekin egia erran: Bonaparteren lana da horren erakuskari. Egun, berriz, irizpideak askoz gehiago dira, hizkuntza maila guztietakoak (ikus, konparazione, Iñaki Caminoren eta Koldo Zuazoren artikulu eta liburu ugariak), eta hiru multzo egin ohi dira: berrikuntzak, forma zaharkituak eta hautuak (ikus Camino, 2009: 388-416).

Horretaz landara, euskalkiak noiz sortu diren, non eta nola aztertzen da, bai eta horretarako izan diren arrazoiak ere (ikus, argibidez, I. Caminoren eta J.A. Lakarraren 2011ko lanak). Hau kontu historikoa da, baina ezin da ukatu eragina baduela, eta handia gainera, egungo euskalarien eta dialektologialarien lanetan, oraingo gauzak aitzineko eta antzinako gertakarien ondorio baitira, hein handian. Alegia, iragana ezagutu behar dugula gaurko errealitatearen berri egokiro eman nahi badugu.

Honetan guztian onomastikak rol handia jokatu behar luke, euskara galdu den Euskal Herriko alderdi zabalean batez ere, baina ez hor bakarrik, anitzetan hango edo hemengo euskara nola edo hala ezagutu arren, ez baitakigu denboraz zer gertatzen zen, nolakoa zen halako tokitako hizkera, hau, jakina den bezala, dinamikoa baita, kanbiakorra, sanjakorra, denboran zehar aldatzen dena. Hizkera galdu baten edo oraingo baten lehengo itxuraren, nolakoaren berri izateko iturri guti ditugu: hiztegi arrastoak, hau da, gelditu diren euskal hitz bakanak (batzuetan itxuragalduak; cfr., adibidez, exkila itxurako lili baten izena den ezkilato, txirikome 'txorikumea' eta saskia Uxuen, artazi 'arte ezkurra' Artaxoan eta zugarro herri honetan eta beste hainbat lekutan) eta onomastika, hots, leku izenek eta pertsona izenek utzi dituzten aztarnak. Orain, egia da, testu txiki franko azaleratzen ari dira, han-hemen, artxibategietako lanari esker. Testu luzeak bakanagoak dira, zorigaitzez.

Euskalkien sorrerari doakionez, hirien garrantzia azpimarratu da: Gasteizena erdialdean eta mendebaldean (ikus Zuazo, 2012: 61 eta hurr.), eta Iruñearena erdialdean eta ekialdean. Ustekari hauek aldezteko tenorean onomastikaren ekarpenak baliatu behar lirateke, zehazkiago erran, Euskal Herriko toponimian ikusten den atzizki banaketa, hau ez baita, nire irudiz, halabeharreko kontua: arrazoi zenbait badateke hala izan dadin, eta aipatu banaketa hori, behin betiko froga erabakigarritzat ezin hartuko badugu ere, ezin utziko dugu, ezta ere, 
bazter eta alde bat, gure irismenean ez balego bezala.

Euskal Herriko berrekailu banaketa ikusirik, geure buruari egin diezaiokegun galderetako bat hau da: zergatik ditugu -ika-dun leku izenak Bizkaian, Araban eta Nafarroako mendebaldean? Erresuma zaharra dela eta, garbi ikusten da atzizki hori ez dela herrialde horretako sartalde guztian ageri, beste aski mendebaldeko ezaugarri batzuekin (barri, baltz, intsaur - untsaur, zubi > zufi, $-a+a>-e a \ldots)$ agitzen denaz bestera, alegia, ez dela Lana ibarrean eta Ameskoetan azaltzen, euskara aspaldi honetan mintzatu ez den Berrotzan baizik. Ibar honetan Gernika, Muxika bizkaitarrekin, Artziniega arabarrarekin eta Mambliga burgostarrarekin bat datozen Cábrega $(<*$ villa] cáprica) eta Zúñiga $(<*$ villa] Vestún(n)ica) ditugu. Hau halabeharreko gauza da edo Euskal Herriko mendebalaren erromatartzearekin lotura duen zerbait? Eta lotura badago, zer agitu zen Erromatar Inperioaren azken gizaldietan eta Erdi Aroko lehenetan toponimo horiek duten bezalako hedadura geografikoa izan dezaten?

Uste izatekoa baita atzizki baten eremu banaketari era batera edo bestera eragiteko gai izan zen indarrak ausaz bestelako gertakariak bultzatzeko behar bezainbesteko pisua ere izan zukeela. Betiere, batasun bat ikusten da hor, edo moda bat nahi bada, baina moda izan dadin nolabaiteko batasuna eta elkar eragina behar dela irudi du, lausoa izanagatik ere, bereziki gurea bezalako herrialde ttipian. Eta ez naiz euskal leinuen teoria zaharraz ari hemen.

Geure buruari egin diezaiokegun bigarren galdeitza da zergatik ageri diren -ain-dun toponimo gehienak (Etulain, Paternain-en tankerakoak) Arabako eta Gipuzkoako ekialdean, Nafarroan eta Zuberoan. Ez litzateke kalte, ezta ere, hondar herrialde horretakoek era bertsuko Biarnokoekin nolako esteka duten argitzea. Hauek franko ur sakonak dira; alderdi hartako adituek erran beharko dute hango izenak nondik heldu diren eta zer bilakaera izan duten. Gero, gure lana haien erranak eta ditugun ustekariak zein neurritan bat daitezkeen ikustea izanen da, eta hortik ondorioak ateratzea, ahalbaz.

Euskal Herriaren barneko aferak, ordea, guri dagozkigu, guk ikertu eta trenkatzekoak dira. Atzizki bakoitzaren banaketa geografikoa argi azaldu beharko dugu, bai baitira oraino argikizun eta azalkizun dauden hainbat puntu, besteak beste Bizkaiko Xemein-en modukoetan (Euskal Herriko alderdirik euskaldunena dugu Markina-Xemein, euskara gehienik ibiltzen dena, iduri duenez) -ain-en aldaera dugun edo beste zerbait, Xemeyn-ekin batean Simengayn, Ximengayn, Xemeingayn ere lekukotzen direlako. Honelakoetan, bistan da, kontu handiz ibili beharra dago, hau da, ikerketa lan sakona egin behar da, dauden aldaera guztiak ikusi eta ondorio argietara iristen saiatu, hau, ahaleginak eta bost eginik ere, beti erraza ez den arren.

Bistan da, bukaeran -ain duten toponimo guztiak ez dira -ain atzizkiarekin bukatutzat aitortzen ahal, akabaila bera eta haren aitzinean dena, ardura, nondikakoak diren argi ez dagoelako. Adibidez, nik ez dakit Arrasaten 1342an ageri den Martin Ortis de Urrupayn-en dugun Urrupain horretan (Bergaran hiru Urrupain baserri ditugu egun, eta XVI. mendeaz geroztik lekukotzen da oikonimoa herrian) etorkiz jabegoa adierazi ohi duen -ain atzizkia dugun ala ez, hor menturaz -pain ezezaguna egonen baita.

Erabaki zuzenak hartzeko, noski, gure antroponimia eta toponimia zaharra (Erdi 
Arokoaz ari naiz hemen) ongi ezagutu behar genituzke, oinarria non bukatzen den eta atzizkia -atzizkia bada eta ez bukaera hutsa- non hasten den antzeman ahal izateko. Konparaziorako, Gesalazko Zurindoain herri hustuaren kasuan badakigu oinarrian dagoen Zurindo hori hipokoristikoa dela, Zurikoain-en (Zurukuain egun) dagoen Zuriko bezala, Zuriain-en iturri den Zuri antroponimoari atzizkiak gehitzearen fruitu. Alegia, badakigu oinarria non akitzen den eta berrekailua non hasten, baina usu ez da hala izaten.

Bide beretik, badaiteke Arakilgo Argindoain herri hustuaren oinarrian inon opatu ez dugun *Argindo izen ttipia egotea, hots, *Argi pertsona izenetik (cfr. Klara eta Lutzia, *Argindo segur aski andronimoa izanik ere) abiaturik eratutako hipokoristikoa. Bestalde, 1458an Azpeitiaren eta Azkoitiaren artean ageri den Usurdayn-azpia toponimoaren oinarrian *Usurdo ote dugun ez da batere segurua, besteak beste *Usur-en moduko antroponimorik, dakigunez, inon azaltzen ez delako. Cfr. Ilurdo pertsona izena, hala ere.

Antzeko egoera korapilatsua dugu -arr(i)ain bukera duten toponimo ugarietan, oro har, ez baitira -ain-dunak bezain aiseki azaltzen ahal: Akorrain (Aldude), Aparrain (Hernani), Apharrain (Arhantsusi, iduriz), Ararrain (Burgu), Arrain (Iparraldea, Ultzama), Atekorrain (Orrio - Makirriain), Baliarrain (Elduain), Barrain edo Biarrain (Segura), Galdarrain (Lizarra aldean), Izurrain (Leaburu), Mondarrain (Larresoro), Olarrain (Benegorri), Otxarrain (Arberatze), Sastarrain (Deba, Zestoa), Zenborrain (Orbaibar), Zuriarrain (Amezketa), e.a. Hauetan denetarik dago, zaharrak (Erdi Arokoak), XVII. gizaldikoak eta egungoak, hangoak eta hemengoak. Bukaera hau aski iluna da oraindik, eta franko dago ikertzeko, argi zerbait eginen badugu.

Bada, bestalde, -ain eta -(a)ien-en arteko txandakatzea, zenbait toponimotan. Kasu bat Urabain (< Urabahin) herri izenarena da, Urabaien deiturarekin, Irabien Okondoko auzoaren izenarekin eta Urabiano herri hustuarekin erka daitekeenez gero. Beste kasu batzuk: Bildain / Bildaien edo Laskoain / Laskoaien (Tolosa, XIV. mendea), Elduaien / Elduain, Elduaraien / Elduarain, e.a.

Gero, hor ditugu Biarnoko eta Aragoiko toponimoekin lotu diren -otz, -oze-dun leku izenak, aurreko ikertzaile gehienen arabera $-a z,-e z,-i z,-o z,-u z$ bukaerak dituztenen sailean sartu behar direnak. Hemen zinez akabaila hori dugunetz ikusi beharko dugu, zeren, errate baterako, Nafarroako Beraskoain-en (gaztelaniaz Belascoáin da) oinarrian Berasko badugu, zergatik pentsatu behar dugu Lapurdiko Beraskoitz-en (egun Beskoitze deritza) berrekailua -oitz dela? Edo, beste etsenplu bat paratzeagatik, Ilurdo pertsona izena badugu, zergatik ondorioztatu behar dugu Nafarroako Ilurdotz-en -otz dugula? Gainera Auritz, Armendaritz(e), Geretz, Gorliz eta beste hamaika hor ditugu, eta holakoen azterketatik ateratzen den ondorioa da atzizkia - (i) (t)z zela, ez erran eta idatzi izan den moduan -atz, -etz, -itz, -otz edo -oitz, e.a.

Beraz, hemen gertakari zabala dugu, Euskal Herri gehienean kausitzen baititugu bukaera hori duten toponimoak, Bizkaiko Muskiz-tik Erronkaribarko Bidankoze eta Uztarrozeraino, baita Euskal Herritik kanpo ere. Arlo honetan, eldarnioak eta sukar ametsak saihesteko, azterketa zehatza egin behar da, toponimo bakoitza nondik heldu den ikusi eta gehiago zein leku izenekin lot daitekeen ikertu behar da. 
Honekin guztiarekin dialektologian atzizki zaharren eta ez hain zaharren banaketa geografikoa aztertzea munta handikoa dela adierazi nahi dut, baina aipatu berrekailuetatik behar bezalako argitasunak atera ahal izateko, gauzak behar bezala azaldu ahal izateko, ikerketa sakona egin behar dela, eta ez bakarrik leku batean, Euskal Herri osoan eta, ahal delarik, baita hartatik lekora ere. Eta horretarako, jakina, ikertzaile prestu eta langileak behar ditugu, eta denbora.

\section{Toponimo ereduak eta toponimo sailak}

Atzizkien hedadurarekin batean toki izenen eredu-banaketa ere aintzat hartzekoa dela iruditzen zait, eredu horietako batzuk errepikatzen direlako, baina beste batzuk, aldiz, egiten ez direlako. Erraterako, Villamaterni (>Villamaderni > Villamaderne) eta Villanañe-ren moduko toponimoak, osagaitzat villa + genitiboan dagoen pertsona izena dituztenak bakarrik Araban aurkitzen ditugu, eta ez Araba osoan, Gaubea inguruan baizik. Horiek bat datoz, uste dut, Burgos eta Kantabria aldeko antzeko beste herri izen batzuekin (cfr. bigarreneko Villapaderne), hots, bada batasun bat hor, zalantzarik gabe hizkuntza bera (latina $\rightarrow$ gaztelania) eta antolamendu bertsua izan dutelako.

Aitzinekoarekin loturik, ikusi behar genuke ea Ehari, erdaraz Ali deitzen den Arabako herria, dokumentazioan Ehali-rekin lehian-edo (aldizka ageri baitira) dabilena ere latineko genitibo batean oinarriturik dagoenetz, laguntzat villa-rik eraman ez arren. Elanvs pertsona izena Iruñan (Arabakoan beraz) lekukotzen da, eta ez da neke *(villa) Elani 'Elanusen lurra, baserria...' formatik, metatesi goiztiar baten eraginez *Enali atera dela kontu egitea, eta hemendik, euskal bilakaera arrunt eta ohikoz, Ehali bihurtu dela aurrenik eta Ehari ondoren. Bidenabar, honek erran nahi luke bokal arteko sudurkari emearen hasperentzea, tankera bereko albokariaren dardarkaritze edo tap bilakatzea baino goiztiarragoa dela. Guztiaz ere, hemen toponimo bakarra dugu eta gehiago behar genituzke seguru egoteko.

Ez naiz hau bezalako dialektologia ikastaro batean etimologiakeriatan hasiko, baina erakutsi nahi dut toponimian opatzen ditugun berdintasun horien azpian harreman sare bat zegoela, zenbaitetan biziki zabala zena (-ana-dun toponimoena, kasu, Erromanian txoil hedaturik zegoen), baina beste zenbait aldiz franko lekukoa, eta jakin badakigu giza harremanek berdinkaratzen dituztela hizkerak, eta harremanik ezak elkarrengandik urruntzen eta bestelakotzen. Honek dialektologiarako balio badu, onomastikarako ere balio beharko du, era laxoago batean nahi bada, baina balio beharko du.

Ildo beretik, bukaeran -uri duten leku izenak, Aberasturi, Belaskuri, Bermuduhuri, Ellakuri(a), Enekuri, Erremelluri, Galbarruri, Giputzuri, Hatumanhuri (honetaz ikus Mitxelena, 1976: 63), Imiruri, Marauri, Maruri, Mutilluri, Nabarruri edo Naharhuri, Obekuri, Otxanduri, Semenohuri, Zeanuri eta besteren taxukoek, osagaitako antroponimoa eta huri dituztenak, bakarrik Euskal Herriko sartaldean eta inguruetan agertzen dira, oker ez banaiz, hots, Bizkaian, Araban, Errioxan eta Burgosen. Ohart bedi irakurlea Marauri, Maruri horiek alde bat uzten baditugu, gainerako guztiak proparoxitonoak (edo aurreproparoxitonoak) direla, gure nafar belarriendako aski «deserosoak», eta bi horiek ere, $h$ ebakitzen zen denboran, *Maráhuri eta *Marúhuri ahoskatuko ziren, hain segur ere. 
Ez nabil zehaztasun-zurrean. Bakarrik eredu horren mendebaldetasuna azpimarratu nahi dut hemen, horren azpian, bistan da, zerbait badelako, arrazoiren bat. Errioxa eta Burgosen kasuan birpopulatzeari zor zaioke, goitik jaitsitako jende haiek sartaldekoak zirela, Bizkai eta Arabakoak, pentsatzen bada. Ez naiz hemen Burgos eta Errioxako euskararen jatorriaz ari, hots, zaharra ote zen, birpopulatzaileek eramana, edo zaharra eta berria aldi berean. Ez da hori oraingo gaia. Ez legoke gaizki isonimoak (eta uste dut hitza asmatzen ari naizela) marrazten saiatzea, gauzak mapetan ikusirik argiago azaltzen zaizkigunez gero.

Aipatutako huri-dun toponimo horiek Berantevilla, Elheni villa eta Lacervilla-ren tankerakoekin lotu behar dira, bestalde, bi multzoen artean antzekotasun nabarmena dagoelako, baita ordena edo hurrenkeran ere. Alderik handiena, hizkuntza bazter utziz gero, erdarazko horien egitura pertsona izena genitiboan + villa izatea, eta euskarazkoetan elkarketa (Otxando + huri, adibidez) erabiltzea da. Ezin atzendu, bestalde, gorago aipatu ditugun Villamaderne, Villanañe-ren erakoak, villa + pertsona izena genitiboan dutenak, hurrenkera alderantzizkoa izanik ere.

\section{Onimoek historian zehar aurkezten duten itxura gehienetan aldakorra, eta honek hizkuntzaren historiaren eta dialektologiaren azterketarako duen garrantzia}

Lehen erran dudan bezala, dialektoen bilakaeraren berri jakiteko aldaera bakoitzean aurkitzen ditugun gertakariak berrikuntzak, ezaugarri zaharrak edo hautuak diren eduki ohi da kontuan eta, argi dago, horretarako euskararen historia ongi ezagutu beharra da. Orain Mitxelenaren eta beste hizkuntzalari frankoren lanari esker, gure mintzairaren azken mendeetako bilakaera lehen baino aise hobeki ezagutzen dugu, baina hau hagitz arlo zabala da, eta gauza anitz daude oraindik eginkizun. Perez Lazarragakoaren moduko testu luzeen aurkikundeak onura baizik ez dakarkigu, eta berdin testu laburrenak ere, baldin edireilea edireile bezain irakurle (edo hizkuntzalari) ona bada, eta ongi dakigu bi ezaugarri horiek ez ohi direla, ezinbestean, elkarrekin ontsa arranjatzen ${ }^{1}$.

Ongi aztertzeko dauden gaietako bat aspirazioarena da. Egun Iparraldean baizik ez dugu, baina antzina Hegoaldean ere indarrean zen, nahiz ez, antza duenez, toki guztietan osagarri berarekin. Lekutu ere ez bide zen alderdi guztietan batera lekutu, honetan ere badira aldeak, eta zalantzarik ez dago gaia behar bezala ezagutzeak ondoren garrantzi handikoak izan ditzakeela hizkuntza gertakari zenbait era batera edo bestera azaltzeko (cfr. arena > *areha > harea, adibidez, hondar gizaldietako hasperena nondik atera den argitzen duena; Lakarra, 2009: 216).

Mugaz alde honetan franko garbi zegoen Araba dela hasperenaren bilakaera aztertzeko herrialderik egokiena, 1025 Donemiliagako Reja delakoa hor baita. Arazo zenbait badira,

1. Maioraren zerrendak (2011) eta haietan oinarriturik Santaziliak (2015) egin duen lan bikaina ditut gogoan. 
halarik ere, dokumentu horretako datu batzuk geroagokoekin ongi konpontzen ez direlako. Kasuren batean ezin arranjatua gure hobena izanen da apika, baina besteren batean gure gaitasun ezetik haratagoko arrazoiak dirateke konponduezinaren erroak. Zernahi ere den, berriki aurkeztu tesian Manterolak (2015) aspirazioaren iraupenaren mapa aldatu du, edo aldatzen saiatu da behintzat.

Oraingo hasperendun hizkerekin alderatzeko, Rejan aspirazioak duen banaketa ikustea interesatzen zaigu, zein silabatan ageri den, $h$ bakarra agertzen den edo gehiago, eta noiz arte. Hau ezaguna da, baina oraindik bada zer erran, hasperena non ez dagoen baina itxuraz egon behar lukeen jakiteko etimologiatan sartu behar dugulako: cfr. Arabako Barrón herriaren izena, Barfone X. mendean, Barhoa Rejan, 1025ean, baina baita 1129an ere, Barron gero, eta honekin batean Arbiganoko 1168-1204 bitarteko Barhones mikrotoponimoa, Los Barrones egun. Cfr. orobat, Erroitegiren eta Done Bikendi Haranaren arteko mugako Barroluzea alhagunea, XVI. gizaldiaren akabailan. Hots, dagoena zer den zehatz-mehatz jakin behar dugu, ahalaz. Bestalde, ez dagoena eta gure iritziz egon behar lukeena zergatik ez dagoen azaltzea menturaz zailxeago eginen zaigu.

Hau ikertzeko toponimoen bilakaera aztertu behar da, eta honetarako, erran beharrik ez dago, toponimia (eta antroponimia, onomastika oro har) ezagutu behar da, gauzen funtzionamenduaren berri jakin behar da. Ezagutza eta jakintza bezain garrantzitsua da, nolanahi ere, datuak izatea. Azken urteotan FDMPV bilduman, eta hemendik kanpo ere bai, agiri franko argitaratu dira, datu asko jasotzen dituztenak, eta orain anitzez errazagoa da, kasu askotan, ez denetan, toki izenen jarraipena egitea, eta horrekin batean horiek erakusten dituzten ezaugarrien segimendua egitea, $h$-rena argibidez. Honek, zernahi dela, badu arazo handi bat, agiri zaharrak erabiltzera usatuak ez direnek ongi neurtzen ez dutena: <h> batzuetan ez da etimologikoa, kontu grafiko hutsa da, eskribauak «hobe beharrez» sartzen zuen, balekibale beharbada inoizka. Kontua hemen, hortaz, $\langle\mathrm{h}\rangle$ noiz den etimologikoa eta noiz den grafiko hutsa erabakitzea da, eta horretarako ageri den lekuneari ohartu beharko gatzaizkio, besteak beste. Eskribau bakoitzaren idatz-usadioak eta garaian garaiko ohituren berri izateak ez digu kalterik ekarriko, noski.

Orain neronek burutu ikerketa lan batzuetatik atera ditudan argitasun zenbait aipatuko ditut, datuetara joko dut, dena tar-tar-tar- jardukian aritzea izan ez dadin. Niketan mintzatuko naiz, alabaina, behar baino gehixeago ezbairik gabe.

\subsection{Oibar harana eta Uxue aldea}

\subsubsection{Bokalen irekitzea edo ez irekitzea}

Lergako Aranbazterra-ren modukoetan garbi ikusten da bertan bazter zegoela, ez baztar. Hemendik izter, maizter eta beste ere bagenituela baiestera (hots, iztar, maiztar ez genituela erratera) bada bide, baina lekuko bat behintzat badugu. Beste aldetik, guk Uxuen piparra erraten diegu pipermin handiei; ez dakit, ordea, gauza zaharra denetz. Pitarra 'ardo mintzen, ozpintzen hasia' ere erraten dugu, baina kasu honetan piter, OEHk bilduagatik, ez bide dago biziki hedatua, eta ez dakit etimologia zein den, hots, forma zaharrak -ar ala -er 
zuen. Murillo el Fruton, Uxueko hegoaldeko mugan, Johan Biper bizi zen 1366an (Carrasco, 1973: 448; ikus orain Salaberri, 2015a).

\subsubsection{Bokal hesketa}

Gaztelaniatik hartutako portillo hitza, bestela ate, esate, harrate, harresate... ere erran izan dena, portillu da Oibar alderdiko toponimo batzuetan (Oibar haraneko eta inguruetako datuak Salaberriren 1994 lanetik ateraiak dira): ARojaportillua (1591), ARoyportillua (1593) (Lerga, Arroia dermioa da); Dorretaco portillua (Eslaba, 1601; Dorreta aurkintza dugu), Portillua (Ezporogi, 1661), Viscar aran portillua (Eslaba, 1770).

Latinetik atera izan balitz portelu(a) izanen litzateke; cfr. Iruña Okako Portelu (1574, Fernández de Palomares, 2007: 191). Egia da -oa >-ua gertatu zela pentsa daitekeela, baina datuak ikusirik ez zait iruditzen hala den. Uxuetik irten gabe, Castillu dugu zenbait aldiz, bestetako eta egungo Castillo-ren partez, behin Gaztelu gisa ere ageri dena (Gazteluondoa, Gaztelondoa alderditik urrun dago Castillo - Castillu - Gaztelu hau).

Arabako hegoaldeko mugan (Salaberri, 1998), Ameskoa - Lana - Allin aldean ere bada: Goico portillua (Biloria, 1686), Bidarmingo portillua (Bidarmin aurkintza, San Martin Ameskoa, 1688), Portilua eta Portillua (Galbarra, 1689 eta 1693), Portilua (Lokiz, 1694), Errecara portillua (Eultz, 1726)... Aintzat har bedi, baita ere, beste alderdi batzuetan portilloa dagoela.

\subsection{3. yod-en tratamendua}

Hurrengo leku izenok ekarriko ditugu ahotara, kontsonante palatalaren bilakaera ikusteko:

a) Jaugia (Auria itxuragabetua orain, Morionesen, baina $<y>$-rekin ere izkiriatua agirietan; Jaugibarrena, Jaugiburua ere baziren) vs. Xaugizabal (Eslaba; egun s-rekin ebakitzen da). Jaugi 'jalgia', 'ateraia' dukegu hemen. Mendiak baitira.

b) Xauzgun (Xauzkunea, Sirgún egun; Eslaba) eta Arrixauzkieta, Arrixauzkuneta (ahantziak, Ageza): Arrijausguneta, Arrijauscuneta idatziak XVI-XVII. mendeetan, baina Arrisauzquneta 1706an, seinale [S] zegoela.

Leatxen, bestalde, DoneJulio zegoen 1584an, baina Domensurio, itxuragabetuxe, 1705ean. Bigarren osagaiaren hasierako <s> horrek garbi adierazten du garai batean [j] zena XVIII. mendearen hasmentarako [S] bihurtu zela. Morionesen 1703ko JuandenoJulio 1679an Joan Dene Sulio zen, Jaun Done Xulio 'San Julián' alegia. X- baina -l- ditugu hemen, ez Leatxen bezala $x$ - eta - $r$-, ikus daitekeen moduan.

\subsubsection{Hitz hasierako herskariak}

Hau gai bihurria da, isoglosak markatzea ardura zailkara delako, partikularzki mende bateko baino gehiagotako lekukoak ibiltzen direnean, baina datuak beti datu dira eta ontzat 
hartzekoak. Hona hemen batzuk:

Butzu / putzu: Andrebutzu (Uxue).

Dekuma: Dekumazarra (Galipentzu).

Dipulatze / tipulatze: Tipulatzeta (Ageza), Tipulatze (Eslaba), Tipulatzea (Galipentzu), Dipulaçea (1530) - Tipulaçea (1591) (Moriones).

Dorre: Dorreko itxaurraldea (Ageza), Dorreta (Eslaba).

Gaztelu: Gaztelondoa (Uxue, 1636), Gaztelusaessa (Lerga, 1604).

Gurutze: Guruzea (Galipentzu, 1710), Guruzealdea (Lerga, 1723), Guruche givela (1717), Guruzeguibela (1736), Guruzezabala (1753) (Uxue).

Gapana (inoiz) / kapana (gehien-gehienetan, Nafarroako alderdi zabal batean).

Gristioburua, Gristiodiaburua (Eslaba, 1591, 1593). Cfr. Lizarraga Elkanokoaren Doctrina Christioaren Cathechima liburua (beltza nirea da). Aldera bedi, halaber, Gizaiduri (Leatxe), Gizairudiaga > Izurdiaga (Arakil) eta Gizaburuaga-rekin (hau Bizkaikoa, ezaguna denez).

Koroa / goroa: Coroagaña (Zare, 1610), Goroabe (Iruñea).

\subsubsection{Hitz hasierako kontsonante multzoak}

Plau, pelau 'laua' (iz.): Plaondoa (Eslaba), Plau (Zare) (Elkanokoak plau darabil, eta Axularrek plaundu), Pelau (Pelaubidea, Pelaumuga, Leatxe). Ziraukin Belauburarra dugu $1580 \mathrm{an}$, itxuraz pelau-ren belau aldaera biltzen duen toponimoa, lehen osagaiarendako beste etorki bat ere proposa daitekeen arren.

\subsubsection{Txistukariak}

Gezari (Ageza - Eslaba - Galipentzu) / gesal (Gesaliturria, Ageza; Gesalaga, Leatxe; Petringesala 'Petriren gesala' Uxue). Araban Gazari interesgarria dago, eta gezal ezaguna da (cfr. Gesalaz / Gezalaz, nahiz hemen asimilazioaren emaitza izan daitekeen).

Zabal, zazu, zoko, zar (Dekumazarra Galipentzun, Trankazarra Murillo el Fruton), baina maiz -xar, -txar elkartuaren bigarren osagaia denean (Errotaxar Lergan, Rotasjár ebakia egun).

Zaldu (orokorra; Leatxen adibidez: Zaldu, Zalduarana, Zaldubidea, Zalduko euntzea, Zalduzarreta; Murillon Garipentzuko zaldua zegoen eta Zarrakaztelun Ollarzaldua eta Zalduzaharra) / Zautelu (Uxue; egun ahaztua) / Xautu, Xautuarana (Zare; orain [x], dokumentazioan batzuetan $\langle$ s $\rangle$, [S] alegia). 
Zirikuzabal (Leatxe). Cfr. Kircu 1025ean Araban, Guircu 1393an. Herri hustua zen hau; Agurain ondoko toponimia txikian behin baino gehiagotan bildu du Guircu- Lopez de Gereñuk (1989)².

Inoiz, hitz barnean, $x>t x$ pausua burutu da, gaztelaniaren eraginez: pasabide estali baten izena den Eslabako Patxape < * paxape (<pasa(tu) eta -pe). Cfr., honen karietara, Izabako Transitope. Egokia da pasatu-ren txistukaria zergatik palatalizatu den galdegitea, baina arraposturik ez dut nik.

\subsubsection{Atzizkiak}

Uxue eta Oibar aldean garbi ikusten da atzizki multzokaria -dui izan dela, ez Orbaibarren, Artaxoan, Ibargoitin eta Iruñerri aldean kausitzen dugun -di berriagoa. Cfr. Ibargoitiko Besollan 1093. urtean daukagun «loco qui vocatur Espelduia», ibar horretan mende batzuk geroago ageri den -di-tik hastantzen dena. Dena dela, aintzat hartu behar da Besolla Urraulbeiti ondoan dela, Tabarren mugakide dela.

Aipatu dudan Uxue eta Oibar haraneko -dui atzizki-aldaera bat heldu da Urraulbeitiko erabilerarekin (Izpicuduia, Geretz, 1692). Ez dakit hau halabehar hutsaren fruitu den edo baden azpian zerbaiten eragina edo, zehazkiago erran, zerbaiten eragin eza. Erran nahi dudana da beharbada Iruñearen eragina ondoko ibarretara zabaldu zela, eta Artederretan barna Artaxoara eta Orbaibarrera ere iritsi zela alde batetik, eta Arangurenen eta Elortzibarren gaindi Ibargoitira beste aldetik, baina ez euskararen eremuaren bazter batean gelditzen zen Oibar haran, Uxue eta Murillo el Frutora (Arandui), edo aski zoko egiten zuen Urraulbeitira.

Oibar ondoan den Leatxen, hala ere, -di dugu Elordia toponimoan, goiko aldean dagoen Ibargoitin dugun berbera. Leatxek, nonbait, harreman handiak izan ditu historian zehar goragoko ibarrarekin, Ibargoitirekin, eta horren erakuskari-edo dateke -dui ez, baizik -di izatea.

\subsubsection{Hiztegia}

Oibar haraneko toponimoetan edireten ditugun ondoko ele hauek aipa ditzakegu, beste askoren artetik: alor, altxirri 'ardi kaka', altxunbide 'altxonbidea, ardibidea', ardantze, berro 'luberria', dekuma, erregu, erreka ('erreka' eta gaztelaniazko gure alderdiko 'barranco'), errekin 'erretako oihan puska', euntze, ezkabia, ezti (edo esti: Udare estia, Udareestiaga, Moriones, 17031704), garai 'zutabe gaineko bihitegia', idoki (Arriydoquieta, Lerga, 1558), igurai, kaskailu, labe, laku 'ura iragazten ez den tokia', makur, sario, xubingo, zapatagin eta zapatagindegia, zarkume, e.a. Cfr., gainera, Barranco del Ibón, Galipentzun, lehena sartaldetik sortaldera joanik, dakigunez.

2. Arabako datuak Salaberri (2015b) lanetik atera ditut. 
Ikusten den bezala, gauza berririk ez dago. Gehienez ere, hitzen aldaerak dirateke interesgarri, dialektologia kontuetarako: dekuma, euntze, igurai, sario, eta beste. Gainera, kasu bakoitzean hitzaren adiera ongi mugarriztatu behar genuke, eta hau ez da beti eginkizun erraza: Uxueko euntze, adibidez, ez zen menturaz Iruñerriko euntze bera, eta zalantzarik ez dago Larraungo euntze-tik bereizi beharra dela. Hots, hitzaren jatorria bera da hiru kasuetan (fenu > *henu > *hehu > *u(n) +-(un)tze), baina alderdi bakoitzean zuen erranahia ez, klimak agintzen baitu, oraingoan. Murillo el Fruton Estellerrian ageri den eutze bera genuen, hots, tarteko sudurkaririk ez duen forma.

Uxueko idoi bestalde, gaztelaniazko balsa-ren adierakidea dena, abeltzaintzarekin lotua da ia erabat, eta ehizarekin hein txiki batean: herri ondoan egon dira idoiak, eta altxonbidearen bazterrean, zamari jendeek eta ardiek non edan izan zezaten, uda parteko idorte latzetan. Zakurrek eta ihizi-basapiztiek ere edan beharra zuten, baita artzain, ahuntzain, mandazain eta bestelako kabalzainek ere, aziendek berek ez ezik.

Aintzat har bedi, nolanahiko gisan, hitz guztiak ez direla sinkronia beretik atereak, batzuk mende batekoak direla, besteak bestekoak eta hirugarrenak hurrengo gizaldikoak. Guztiarekin ere, hauek dira alderdi honetako euskararen lekuko bakarrak, oraingoz, eta horregatik ezin arbuiatuzkoak.

\subsection{Ameskoa eta Lana}

Eremu hau, Araba ondoko Burunda bezala, hagitz interesgarria da. Zehazkiago erran, hagitz interesgarria da hiruren artean (Burunda, Ameskoa eta Lanaren artean) ageri den hein bateko batasuna, eskuinekoetatik (Nafarroako beste hizkeretatik) bereizten dituena. Burundako hizkeraren inguruan Zuazo (2010) ikus daiteke orain. Beste bietan euskara lekutua da eta ez dugu testigantza askorik. Neronek Artatzan agertutako testua aztertu nuen artikuluxka batean (Salaberri, 2004).

\subsubsection{Despalatalizazioa}

Toponimian badira errepikatzen diren hitz batzuk, beren barnean soinu palatala, edo palataliza daitekeena, biltzen dutenak. Ohikoena hamaika leku izenetan kausitzen dugun gaina da, batuan, hizkera arrunteko hitza denean, <in>-ekin idazten duguna, baina toki gehienetan [n]-rekin ebakitzen dena.

Ameskoa eta Lana aldean garbi ikusten da denbora batean $<\tilde{n}>-z$ izkiriaturik azaltzen ziren toponimoek egun, hizkuntza aldatzea izandako lurrikara izugarritik onik-edo (gehienak itxuratxartuak) atera direnean, ez dutela soinu palatalik, goragoko Burunda aldean agitzen denaren ildotik. Hau garrantzizkoa da ibar honen, Ameskoaren eta Lanaren artean bilakaera

3. Ikus Salaberri (1998). 
komuna egon dela adierazten duelako, nahiz erdian Urbasa-Entzia eta Lokiz mendiak egon.

Ondoko Arabako Haranean zer gertatu den ikusteko baditugu lan batzuk: Lopez de Gereñuk 1989ko liburuan bildutako lehenagoko, 1956-1979 bitarteko datuak, 1983ko artikulua eta Mitxelenak 1971n (azkeneko hiru orrialdeak partikularzki) eta 1985ean datu haien gainean erranak.

Gipuzkoar hizkuntzalariak (1985: 601-602) dioenez, sartaldeko hizkera dugu Kontrastakoa, leku izenetan ikus daitekeenez: - $a+-a>-e a$, -ia, buar 'bularra', barga, barri, -dui, -gan (baina -gain gehiago), inkatz, larrin, narrutu, oste. Ondoko nafar alderdian bezala, eliza, soro eta zufi azaltzen dira, baita aiz- ('haitza') ere. Mendebalderago ere az- dugu Maeztuko egungo Azkorri-n (González Salazar, 1986: 47), baina gana, Bernedo aldeko Markiz herrian, kasurako.

González Salazarrek (1986) Guirigaina, Ollargaina (cfr. Chorogana Arluzean [ibid., 39], Mendigaña Apelaizen [ibid., 43], San Vicentegaña Maeztun [ibid., 45]), Ordinasoro, Sagarmina, Artiarana, Larradana, Ocaratirana (< okaranak dirana?), Zumaduya, Arancaicha (< Arangaitza ustez; cfr. Turrigacha, Recagacha Arluzean [ibid., 39]) eta Mindurina (ibid., 37) biltzen ditu Kontrastan.

Nafarroako ibarrei doakienez (Salaberri, 1998), Arzurigaina (1735), Aizurigaina (1751) zena (harri + zuri + gain + - a / haitz + zuri + gain + -a) Izurigáina, Izurugáina da orain Aranaratxen eta Eulaten. Larragoako Arzagaina $(1630,1859)$ Arzagáina da gure egunotan. Herri honetako Cañueta (1634-1705) 1825ean Cainueta zen eta gaur Kainuéta. Altsasun, diodan bidenabar, kainuba 'el caño' erraten zuten hango euskara egiten zuten azken hiztunek (Izagirre, 1967: 70).

Ameskoabarrenean Mendigáina, Oribiagáina, Trungáina eta beste ditugu, eta Biloriako dokumentazioko Mendigurengaina, Mendiburugaina gaur egun Mendilugáina da. Ez da hau gaia garatzeko lekua, datuok argitaraturik baitaude gainera (Salaberri, 1998), baina ezin aipatu gabe utzi Larragoako eta Lokizko Mendiluina (1859), Mendiluina orain, mendi + iluina 'iluna' etorkiz.

\subsection{2. $-b->-f-$}

Aldakuntza hau Rejan aurkitzen dugu, 1025ean: Zuffia de suso, Zuffia de iuso. Gero hau dugu: Zuhigutia (1223), Çoygoytya (1257), Çuygoitia (1276), Cigoitia (1393an), eta hauekin batean baita Zuhia (Zuia, 1025) eta Zufia (1089) ere.

Nafarroako Burundan ez da zufi ibiltzen, baina badira -b- >-f-ren lekukotasunak (Iturfe Iturmendin eta Urdiainen, Mendife Ziordian, adibidez). Agurainen Arzufia eta Arrizubibeitia zeuden duela 85 urte (Grandes, 1929: 139-140). Bigarrena Arriçufibeytia zen 1512an, Altzania aldean (Pozuelo, 2001: 257). Ameskoetan zufi ageri da: Gurzufia (1693), Gurzúfi egun (Larragoa), Zufia dana, Zufikoa (Gollao, 1726, 1729), Zufieta (1710), Zufiéta orain (Gollao), Zufikia dana (Barindao, 1710), Zufikoa dana (Bakedao, 1696), Zufitxarkia (1691), Zufizárki egun (Larragoa), e.a. Allingo Eultzen Astazufikoa genuen 1819an. 
Ezaguna denez, Estellerrian bada Zufia herria, Zubielki deritzan beste baten mugakide dena, biak Allin ibarrean, Lizarrari hurran. Gertakarien mugak nonbait egon behar eta hortxe egoki! Harrigarria da, dena dela, herri batek $b$ izatea eta aldamen-aldamenekoak $f$. Nafarroako Zufia hori ere ez da berria; XIII. mendean kausitzen dugu, eta badakigu -a kendu-utzizkoa zela, Orti Çufico baitugu, gizaldi horretan.

Honen parean, Zufigaña dugu Ega ibarreko Antzinen 1699an, Bengo zufia Lanako Galbarran XVII. mendearen bukaeran, Zufipunta 1700ean, Zufitondoa Gastainen 1675ean, Zufitondobarrena 1687an. Beheiti aldera, Errioxan, Zufiori genuen 947. urtean (hau dateke -b- >-f-ren lehen testigantza), Zufiuri 1057an, Cihuri izkiriatua egun.

Mitxelenak Lopez de Gereñuren lanetik hartutako Kontrastako Arteko zufi dakar. González Salazarrek (1986: 33, 37) Sufimuso biltzen du Aldan (*Zufimusu?), eta Zarrazufi Kontrastan.

Martinez de Madina arabar onomastikariari esker dakit Haraneko Alda herrian Yribarrizuficoadana toponimoa genuela XVII. gizaldian, jatorriz «Uribarriko bidean den xubi ttikiaren ingurua». Toponimo honetan lau gauza dira garrantzizko, gutieneko kontuan: lehena holako toponimo euskalduna agertzea bera, nahiz hau, alderdia ezagutzen badugu, ez den harritzeko; bigarrena ikusten ari garen $-b->-f$ - aldakuntzaren beste lekuko bat izatea, $-k o$ atzizki txikigarria duena, gainera (zufikoa). Notatzeko hirugarren puntua zera da, Satzname eder bat dugula, eta laugarrena, lehena izan behar lukeena agian, Harana ibarreko Ullibarri herria euskaraz Uribarri ez, baizik Iribarri zela garbi adieraztea, hots, erdi-ekialdeko hiri eta mendebaldeko barri osagaiak elkartzen dituen aldaera zela.

Honek zer erakusten digu? Ba, ezbairik gabe muga edo iragate eremu batean gaudela, toponimoek Araba aldeko ezaugarriak eta Nafarroa aldekoak dituztela, batera zenbait aldiz, oraingo honetan bezala. Hau bereziki garrantzizkoa da euskara lekututako alderdia delako, testu gutxi utzi dizkiguna (ikus gorago, Mitxelenaren 1985eko hitzak, gai honetaz): Sabando ez dago urruti, baina Juan Bautista Gamiz Iruñean bizitu zen, eta haren euskararen ezaugarri batzuk Iruñeko eta Nafarroako euskararenak dira, ez egilearen sorterriko hizkerarenak. Artatzako testua aipatu dut dagoeneko, eta ez da nahi genukeen bezain luzea.

Bada, honen kari, beste gauza bat polita, nabarmentzea balio duena: Arabako mugan baina Lokizez beheitiko aldean («Lokizen erdian» erratea zehatzagoa dateke) dagoen Nafarroako Lana ibarrean beste hainbeste agitzen da: hor (ere) bada erdaraz Ulibarri deitzen den herria (Arabakoa Ullíbarri da), euskal mikrotoponimian gehienetan Iribarri izendatua azaltzen zaiguna (Yribarribidea, Yribarrico muga, Galbarra, 1649 eta 1691; Yribarribidagayna, Narkue, 1694). Bada, baita ere, Iribartia izeneko dermioa Gastiainen, oker ez banaiz Iribarrigutia herri hustuaren izenaren bilakaeraren emaitza dena; pentsatzen dut Iríbarrigutia ebakeraren ondorio datekeela aipatu aurkintza izena. Lanako oraingo Ulibarri, XIV. mendeko agiri interesgarri 
batean, ${ }^{4}$ Iribarri mayor, Uribarri mayor ohi da, ezbairik gabe Iribarrigutia-tik bereizteko. Ezin ahantzi, buruenik, Egaibarko Mendilibarri herri izena, dokumentazioan, berandu arte, Mendiribarri eta Mendiriberri aldaerak, batean, aurkezten dituenez gero.

\subsubsection{Baltz / beltz}

Ekalan Bidebalz dago 1710ean, Araiztubelza, Ariztubelza-ren aldakan. Azken hau egun Aristubélza da, Eulaten bezala, nahiz hondar herri honetan 1688an Araiztubalza azaldu. Borroka ikusten da, hortaz, bi Ameskoetan, baltz eta beltz aldaeren artean, Lanan bezala. Ibar honetan Loguibalza agertzen da Gastiainen 1685etik, baina Aranbelza dago Bilorian XIV. mendean, Galbarran 1639an, Aranbelça Lokizen XIV. gizaldian, Aranbelz 1824an, Aranbél egun.

Bilorian Johan Balça zegoen 1350ean, eta Gastiainen «Maria Landa alias Maribalza» 1696an. Azken honen anaia bide zen «Juan de Landa alias Moreno» ere azaltzen da, eta honela deskribatzen: "Ytten a Juan de Landa alias Moreno natural de d[ic]ho lugar de hedad de veinte y cinco años moreno de cara pelo negro liso barbilanpino y de mediana estatura». Garai hartan argazkirik ez egoki!

\subsection{4. erreka / errekea}

Bukaeran - $a$ duten hitzetan artikulua gehitzean gertatzen den disimilazioa, hots, $-a+-a>$ -ea, lehen aldiz, 1025eko Rejan aurkitzen dugu, Elhorzahea-n (Manterolak [2015] Morebiribilearen moduko inesiboarekilako aldaera analogikoa dakusa hemen). Guk oraino argia ikusi ez duen lan batean duela hiru urte genioenez, menturaz sobera bakartua dagoke testigantza hau, baina orain badakigu ez dela bakarra, badela beste bat Errioxan, Garci Olhea, 1156 aldean, Casalarreina inguru horretan (Ag. Ubieto, 1978: 31). Hemen, garbi dago, olha +-a dugu.

Disimilazio hau, beraz, franko zaharra da, eta nik errranen nuke pisurik aski izan duela eta beharbada oraino badukeela dialektologia lanetan. Gipuzkoako Goierritik Nafarroako Burundara doa isoglosa, eta Burundatik badakigu Ameskoagoienera jaisten zela, Entzia eta Urbasa gainditurik, eta hemendik Lana ibarrera, oraingoan Lokiz mendia iraganik. Hau da, Arabako mugan dauden alderdiak harrapatzen ditu: Bizkaia, mendebaldeko euskara egiten den Gipuzkoako alderdia, Goierri, Burunda, Ameskoagoiena eta Lana, egungo Euskal Herrian, baita Errioxa ere, Euskal Herri galduan. Gipuzkoako kostaldeko azkurea, Nafarroako aterea eta tankera horretakoak alde batera utziko ditut hemen.

Errioxako aferak bihurrikarak dira eta ez dira hemen ukitzekoak, ez da egungo gaia. Hango euskara antzinatikakoa izan edo Ebro igarota alderdia birpopulatzera joan zirenek eramana izan, kontua da Olhea badugula, eta beste gauza franko ere baditugula XII eta XIII.

4. Lankide dudan J.M. Lana Mikeas-i zor diot dokumentuaren ezagutza. Bihoazkio hemendik nire eskerrik beroenak. 
mendeetan (lehen aipatu dugun huri adibidez), Arabako hego-sartaldeko ondoko alderdian erromantzea nagusi zen garaian.

\subsubsection{Hiztegi kontuak}

Ondoko ele hauek aipa daitezke, besteak beste:

Baratza: Andiko baratzak (Aramendia, 1697).

Barga: Barga (Arellao, 1752), Barganarrutua (Lokiz, XIV-XVII), Bargabitartea, Bargaondoa (Bakedao - Gollao, XVIII), Bargatxipia, Bargatxipigaina (Ekala - Eulate), Bargazuria (Eulate, XVII), Daliko bargaeskina (Eulate - Aranaratxe).

Boru 'errota': Borualdea (Gastiain, 1689), Boruartea (Narkue, 1692), Boruzarra (Gastiain, 1692). Lanan ez dugu errota-rik aurkitu, eta Ameskoan, berriz, ez dugu boru-rik opatu: Errotabidea, Errotara bidea (Barindao, 1712, 1719), Errotaldea (Aranaratxe, 1613; Zudairi, 1705), e.a. Guztiaz ere, halabeharreko gauza izan daiteke.

Larrin: Larrinburua (Biloria, 1685), Bengo larrina (San Martin, 1690), Larrinabuarra (Larragoa, 1697) (cfr. Gomiz de Larrinhetago, Araban, ustez, 1129an) / larrain: Larrañeta Larrinetako eguia, Larrinzurieta (Zudairi, 1686, 1688), Larrineta - Larrañeta (Lokiz, 1692).

Narrutu: Barganarrutua (Lokiz).

\subsection{Artaxoa $^{5}$}

\subsubsection{Deklinabidea}

Artaxoan -(r)e genitibo sudurkarigabea zegoen, Oteitza, Orbaibar eta Uxueko - (r)en aldaeraren aldamenean: Mariaren gortea, Pa [s]coalengorteac (Oteitza, 1574, 1578), Petringuesala (Uxue, 1593), Piquero aren berroa (Eslaba-Epaitz, 1648), Calvoren corrale sarraldea (Eslaba, 1692), D[o]n Juanen barrancoa (Uzkita, 1823), e.a. Artaxoan, aldiz, ondoko hauek aurkitu ditugu dokumentazioan:

Antsare gortea, Antxapale gortea (Antxo Txapel; «Sancho Chapel fi de Katelina» dago dokumentatua), Arotzare gortea, Azearitze portalea, Errabiare gortea, Gile gortea, Gile olibadia, Juan Rose sakana (= Juan Ros sakana), Kastañare gortea (Elvira Castayn), Lopere zazua (= Loperen zazua), Mariare gortea, Marimigeleze gortea, Mateare gortea, Olatare gortea (Semero Oblata, Sancho Oblata...), Paskuale gortea, Remone gortea... Inoizka, ikusi den bezala, -rena ere agertzen da. Cfr., gainera, Aitagomeçarena (1338), Aytameçare (1595), Garziaren saroia.

5. Jimeno eta Salaberri, 1998. 


\subsubsection{Hiztegia}

Toponimoetan edireten ditugun eleekin hiztegi txiki bat egin daiteke; hona hemen horietako batzuk:

Ahuntz (Aunzbidea, Aunztegia), aker (Akerbelarra, Akermendia), alor (Auzalorra, Bodinalorra, Irantzualorra), apez, apeztegi (Apezalorra, Apeztegiko baratzea), arantze (Arantzedia), ardantze (Ardantzemakurra), artzai (Artzaiportilloa), arotz (Arotzare gortea, Arozmendia), axari (Axarikortea, Axarizuloa), baratze (Baratzea), belatz (Belatzmendia), bidegurutze (Bidegurutzea), dinda 'kalexka', 'bidexka' (Barrendinda), dorre (Dorreberria), eri (Erietxea), esate (Gatuzuloko esatea), estali (Gortestalia), galtzinalabe (Galtzinalabealdea), gatu (Gatuzuloko esatea), gatz (Gazbidea, Gazpidea), gaztelu (Gaztelugortea, Gazteluzar), gesal (Gesalea), haizerrota (Aizerrotamendia, Aizerrotondoa), harakin (Arakindermioa), harmaskadi, harrimaska (Andrearrimaska, Armaskadia), idoi (Gentzeko idoia), ilun (Araniluna), jaun (Jaunazeritzea), labur (Antsalaburramendia), luze (Arriluzea), mairu (Mairumendia), makur (Ardantzemakurra), mehar (Zubimearra), mukuru (Armukurua), olibadi (Gile olibadia), parrale (Parralea), portale (Azearitze portalea), sakan (Juanrosakana), sandu (Sanduzuria), saroi (Garziaren saroia), serore (Seroreiturria), txapel (Antxapele gortea), Txirri(a) (Txirriturria), uharka (Uarka), urkamendi (Urkamendia), zazu (gaztelaniaz saso da: Loperen zazua edo Lopere zazua, Zazuandia, Zazuertea, Zazuluzea), zerko ('harresia': Zerkondoa), zidor (Andionzidorra, Estellazidorra), e.a.

Pertsona eta toki izenak: Antsa, Antxo Txapel, Arrapat, Azearitz, Castain, Gometza, Eneko Argedasko, Estella, Ferran, Garzia, Gil, Irantzu, Lope, Olata...

Toponimoetan oinarri harturik, Artaxoako euskara galduaren ezaugarri batzuk ikus daitezke:

Bokalen bilakaera: Azearitze portalea / Jaunazeritzea / Axarikortea, Axarizuloa.

Sudurkari galtzea. Badakigu Euskal Herriko beste lekuetan bezala -ana latinetikako atzizkia -a bihurtzen zela: Akitana toponimoa Aquita da 1402ko lehen lekukotasunean. Hasperenaren aztarnarik, bidenabar, ez dago. Badakigu, orobat, -ano >-ao, -au egiten zela: Kapillao, Kapillau.

Ahoskabetzeak: Gazbidea vs. Gazpidea.

Palatalizatze kontuak: Araniluna, Gile gortea vs. Gille gortea.

Kontsonante bakuntzea: Olatare gortea (Semero Oblata).

Protesia: Arrapatietxondoa (Garcia Rappat, Miguel Rapat), Errabiare gortea (Errabia, Rabia).

Paragogea: Eskopalea, Eskopaleondoa (cfr. Uxueko Eskobarea eta Zareko Utsaskieta).

Disimilazioa: Barrendinda > Barredinda. 
Haplologia: *Antxo Txapel > Antxapel(e gortea).

Atzizki eta bukaerak:

-di: Arantzedia, Armaskadia, Lezkadia, Zuasti, Zumadia.

-eta: Argongeta, Armugeta.

-gin: Arakindermioa.

-ko: Barberzarkoa.

-ngo: Iturringoa.

-(t)egi: Apeztegiko baratzea, Aunztegia.

-zai: Artzaiportilloa...

Garbi dago Artaxoako testu txiki batek (cfr. orain Santazilia, 2015: 135-137) gehiago erakuts diezagukeela ezen ez ikusi ditugun toponimoek, baina testuak eta onimoak elkarren osagarriak izan daitezke, izan behar dute, ez elkarren etsai.

Nolanahi ere, badira aipatu ditugun horietan gauza interesgarriak, Artaxoako hizkera galdua (Jimenoren lanari esker badakigu, derragun bidenabar, XIX. gizaldiaren hasieran lekutu zela) ezagutzeko eta kokatzeko balio dutenak. Berezitasunik handiena, ezbairik gabe, oso ongi dokumentatua dagoen sudurkaririk gabeko genitibo morfema da, ondoko herrietako aldaeratik urruntzen dena. Itzarbeibarko euskara ongi xamar ezagutzen dugu (Bonaparte Ondarra, Ukargo katixima, Utergako Beriainen lanak...), eta beti - $n$ dago. Orbaibarren eta Uxue aldean ere, ikusi dugun bezala, -n-dun aldaera dugu, eta berebat Oteitza alderdian.

Bestalde, saroia dugu (ikus orain Zaldua, 2015), Iruñean (Jimeno eta Salaberri, 2006: 316-317), inguruetan eta hortik beheitiko eremu zabalean arras hedatua zegoen sario-tik hastantzen dena. Sandu, kontrara, ongi arranjatzen da Iruñerriko eta bestetako datuekin (Sanduandia, Sanduzelai hiriburuan), zandu-ra «iristen» ez bada ere (cfr. Artzibarko Zandueta herriaren izena).

Gainerako item lexikoak eta aldaerak eremu honetan espero genituenak dira. Adibidez, erregu Murillo el Frutoko Erteko erregua 'arteko erreka'-rekin, Leatxeko Erregumaiorea-rekin eta Galbarrako Behengo erregua-rekin bat dator. Portalea harresietakoa da, Galipentzuko Portaletxikia-rekin bat heldu dena. Dinda hitzak, aldiz, Uxuerekin (drinda) ez, baizik Orbaibarrekin (Dindaartea, Dindaertea, Amatriainen, baina Drunda Oletan) eta hiriburuarekin lotzen dute Artaxoako hizkera: cfr. Iruñeko Dindatxikia, Urradinda, Zakudinda. Orobat Iruñerriko eta Imozko behialako hizkerekin.

Atzizkiei doakienez, Iruñerriko, Orbaibarko eta Itzarbeibarko -di dugu, ez Murillo el 
Fruton, Uxuen eta Oibar haranean dagoen -dui (idoi bezalako hitza berezia da; ikus Salaberri, 1991). Artzai-ren modukoak ohikoak dira Nafarroako erdialde zabalean, eta orobat baratzeren tankerakoak. Bada -ngo atzizki txikigarri eta hipokoristikoa, han-hemenkako Zubingoa, Xubingoa-n kausitzen duguna.

\subsection{Luzaide $^{6}$}

3.4.1. Luzaiden, lehenbizi, orain ibiltzen ez direnak baina denboraz egiten zirenak nabarmen daitezke: beitiko (Beittico-echea, geroko Pekotxeta), errota (Errotaburua, 1644, 1801 arte erabilia, gutxienez), errotazai (Errotaçayarena, 1644)... Egun ihára, ihazáina erraten da (-zain da atzizkia), eta erróta 'gurpila' da.

\subsubsection{Hasperen kontuak}

Batzuetan hasperenketa opatzen dugu, gaur, jatorrizko -r-ren ordainetan. Badaiteke, zernahi gisaz, tarteko urratsa -rh- izatea: ahának 'aranak', ahakái 'haragitako ardia' (arakai < haragi + gai), ahátxe (< aratxe), ahótz (eta aótz, arotz-etik), bahátze 'baratza', behánt eta behantétsi, behéxi 'bereizi', ehótu (hau erótu-rekin batean), gehézi, kuhutzátu, kuhútze, e.a. Ildo beretik azaldu beharko da Ondarrolako Zentzahane izeneko auzoa (J. Camino, 2008: 41), Celzaran lekukotua, etxetzat, 1770ean (Satrustegi, 1965-66: 29).

Egurtzegik (2014), doktore tesian, -rh- > -h- bilakaera proposatzen du. Dena dela, Burdinzuhia oikonimoaren kasuan hau ezinezkoa da, ez da *Burdinzurhia moduko batean pentsatzen ahal, Burdinzubia-n baizik. Egungo Zujáundja ere Zubiandi ageri da 1852an, eta hemen ere orain lekutua den hasperena proposa daiteke tarteko pausotzat (cfr. Arabako Zuia). Hortaz, badirudi hasperena zuzenean igurzkari ahostun batetik atera zitekeela.

Bestalde, 1770eko Cehiarena oikonimoa, egungo Xehjáinja, Seriarena da 1786an, eta honek pentsarazten digu orduko tap-a hasperentzen hasia zela, oikonimoaren etimoa zehea 'xehea'-n oinarritu Zehea izengoitia dela iduri baitu. Seriarena hori ultrazuzenketa baten ondorena dela, alegia.

3.4.3. Dialektologiarako interesgarria da leku izen hutsen eta oikonimoen euskarazko eta erdarazko aldaeren artean dagoen aldea zein den jakitea, hau euskal item lexikoen bilakaera aztertzeko (edo aztertzen laguntzeko) bide delako. Erkaketatik, adibidez, bokalen eta diptongoen bilakaeraren inguruko hainbat aztarnaren berri jakin daiteke, zenbait kontsonanteren jokabideaz eta azentu kontuez puntu interesgarriak ikas daitezke, eta galeren data ere zehatz daiteke, hein batean segurik. Hurrengo pareetan lehen forma euskarazkoa da, eta bigarrena gaztelaniaz ibiltzen dena:

6. Datuak ateratzeko oraino ere argia ikusi ez duten P. Kamino eta P. Salaberriren bi lan hauek ibili ditut: Luzaideko euskararen deskribapena eta Luzaideko etxeen izenak. 
3.4.3.1. Amalláinja / Amalláu (Amalau, 1852, 1886), Mikeláinja / Mikeláu. Erdarazko aldaerek bukaerako atzizkia galdu dute, baina diptongoari eutsi diote. Euskarazkoek, aldiz, [au] > [ai] egin dute, nahiz akabaila atxiki duten. Diptongoaren bilakaeraren karietara, erran behar da adizkietan ere ohikoa dela bimorfismo hori ([aun] / [ai]]), baina jakina, euskararen barnean oraingoan: kárri dáuxuut / kárri dáixut 'ekarri dixut' ('ekarri dizut' xuka), emán dáuxu / emán dáixu 'eman dixu' ('eman dizu', xuka), galdín dáuzje / galdín dááizje 'galdegin dizue', 'eskatu dizue'; eróri záuzu / eróri záizu. Lehen bikoteetan [aun] da zaharra, *eradun aditzaren formak baitira (cfr. B. Etxepareren «erdiratu deraudazu bihotza», «joan daraudazu lehen bihotza» 'eraman didazu lehenik bihotza', e.a.). Nor-nori saileko adizkiei dagokienez, berriz, [ai]dunak dirateke zaharrenak, baina, nolanahi ere, B. Etxeparek irudi baçautzu / ezayçula herabe darabiltza, hots, [aun] nahiz [ain] dituzten adizkiak. Dena dela, au > ai aldakuntza, ekialdeko beste hizkera batzuetan agitu denaz bestera, ez da Luzaideko hizkeran nagusitu, apika eta hein batez, hasperenketa gorde delako: ahúntza, gáuza, e.a.

3.4.3.2. Andikórrja («Andikoorriko semea», XX. mendearen bigarren erdiko testuetan) / Andikobérri. Ikus daitekeenez, euskarak bukaerari (artikuluari) eutsi dio, baina iguzkaria desagertu da, bokal arteko lekunean. Gero, elkarren ondoan gelditu bokal berdinak batu dira, berriki, itxuren arabera.

3.4.3.3. Antxwizénja / Antxúriz, Páisja / París. Bikote hauetan euskarazko formek bukaera atxiki dute, eta tap-a galdu; erdaraz ibiltzen den aldaerak, aldiz, bukaera ez du gorde, baina bai tap-a. Ditugun lekukoak ikusirik, erran daiteke hondar soinu horren galera berria dela, hogeigarren mendekoa, baina hau ez da izen guztietan hola izan: Gainndóla < Gaindola (1800) < Garindola (1773). Tap horiek, egungo hizkeran, zenbait aldiz erortzen dira, baina beti ez: Mezkiitze, paéta baina abére, denbóra, erakútsi..., eta batzuetan agertzea edo ez agertzea hautazkoa da: atéa / atéra 'atera, irten', goráintzi / goáinntzi, orái / wái 'orain'.

3.4.3.4. Arranegi (XVII) > Arnegi (XVIII). Handi-handika. Arnegizar > Arneizar (XIX. mendearen azken laurdenerako, ditugun datuen arabera). Baina ikus bedi Zapatainarena, beherago.

3.4.3.5. Àuntxaináinja / Auntxáina. Aunzañarena XVIII. mendean (1726an). Ohart despalatalizazioari eta tap-aren erortzeari. Hondar honen kari, cfr. Barberarena (1786) / Barberainea (1852), eta batez ere Dorre (1786) / Dorreina (1800), Venttarena (1786) / Bentainea (1801), nahiz Ernandorena ere (1786 eta 1801) izan.

3.4.3.6. Bartzelona, Bartzalona / Barzelona. Hemen txistukariaren afrikatzea dugu euskaraz, dardarkariaren gibelean, baina ez gaztelaniaz. Bestalde, gure hizkuntzan bokal asimilazioa anitz aldiz gauzatzen da; ez ordea erdaraz.

3.4.3.7. Bidártja / Bidárt eta Edarréta / Edarrét. Bi pare hauetan argi ikusten da euskaraz bukaerako bokala(k) atxiki d(ir)ela, baina ez erdarazko erabileran. Hau menturaz gaztelaniari ez, baizik beste latin hizkuntza bati leporatu beharko zaio. Maatxéta / Madarítx parean, aldiz, igurzkari ahostuna erori egin da euskarazko aldaeran, bokal arteko lekunean; erdarazkoak, bestalde, XVII. gizaldirako lekukotzen den atzizkia eskas du. 
3.4.3.8. Errekulusa / Reclusa. Lehenak e-protetikoa eta -u- anaptiktikoa ditu, ikus daitekeen bezala. Erdaraz idatzitako dokumentazioan beti gaztelaniazko aldaera kausitzen dugu. Euskarazkoa arotzaren testuetan ageri da, dakigunez, aurrenekoz, 1880. urtean.

3.4.3.9. Gáinekólta, Ganikólta / Gañekoleta. Gañicoleta (1764), Gañecoleta (1786) dugu agirietan, Gonicolta (sic) arotzaren euskal testuetan, 1880an (< gaineko + ola + -eta > Gañeko óleta > Gainekólta euskaraz / Gañecoléta gaztelaniaz), baina Pekotxéta $(<$ peko + etxe + -eta) bi hizkuntzetan. Cfr. palatalari doakionez, Gañeco echea (1677tik 1801era) vs. Gainecoeche (1886). Azentuak eragindako sinkopa dela eta, Undárla / Ondarróla auzo izenarekin erka daiteke, honek euskaraz bokala galdu baitu, baina ez erdaraz. Iduri luke azentuatzeak bana direla, hots, Ondárrola-tik eta Ondarróla-tik abiatu behar dugula, hurrenez hurren. Sudurkari aitzinean $o>u$ hesketa bakarrik euskaraz burutzen da, ez gaztelaniaz. Tankera berekoa da Lézta (< Lézeta), Leceta 1801ean, Leçeeta 1284an. Cfr. Azoléta (gehienetan) vs. Azólta (inoizka) euskaraz, Azoléta beti gaztelaniaz. Despalatalizazioa dela eta, cfr. Ferraguillearena (1677, ahantzia egun). Franko garbi dago alboko sabaikaria ibiltzen zela, egungo hizkeran ez bezala.

3.4.3.10. Garnada / Granada. Hemen aldaera zaharra bigarrena da, gaztelaniaz oraino ibiltzen dena. Euskarazkoak metatesia izan du.

3.4.3.11. Goenétxja / Goienétxe. Oraingoan ere, erdaraz ibiltzen den [j]-dun aldaera da zaharrena, baina badakigu 1726rako soinu hori lekutu zitekeela, Goeneche ageri baita data horretan.

3.4.3.12. Hargináinja / Argína. Euskarazko aldaerak hasperena gorde du, baita oikonimoetan hainbeste aldiz aurkitzen dugun atzizkia ere.

3.4.3.13. Iribárnja / Iribárne. Yribarren dugu 1677 an, baina Yribarne mende erdi bat geroago, 1726an.

3.4.3.14. Kitterjáinjja / Kitérja, Marttinóinja / Martiño. Euskarazko aldaerek ahoskabe palatalizatua erakusten dute; ez ordea gaztelaniazkoek. Zaila da hizkuntza honetan izkiriatu dokumentuak baliatuz argia egitea, afera honen inguruan.

3.4.3.15. Turbúrja / Turbúru. Biek galdu dute hasierako bokal palatala, hizkera arruntean agitzen den moduan (bada salbuespen zenbait; ikus Kamino eta Salaberri, 2007: 179), baina 1726tik XIX. mendearen bukaera arte Yturburu, Iturburu dugu dokumentazioan.

3.4.3.16. Xapitelénja / Txapitél. Hemen zaila da hasierako txistukariaren bilakaera aztertzea, iguzkari eta afrikatu sabaikariak irudikatzeko $<$ ch $>$ erabili izan delako, hots, neke da igurzkaria noiz hasi zen erabiltzen zehaztea, zaharrena afrikatua baita, baina hori ez da, nonbait, euskararen barnean gauzatu aldakuntza.

3.4.3.17. Zapatainarena (1764). Egun ezezaguna da oikonimoa, baina oraindik zapataina 'zapatagina' erraten da, duela 250 urte bezala. Alegia, honi esker badakigu $[\gamma]$ 1764rako erortzen zela edo eror zitekeela, hitz honetan behintzat. 


\subsection{Iruñerria}

Ez ditut hemen Iruñerriko ibar guztiak hartuko. Alderdi honetako euskara neurri batean behintzat testuen bidez ezagutzen dugu, baina gorago erran bezala, onomastika datuek ez dute kalte egiten.

Geure buruari egin diezaiokegun galderetako bat da zergatik azaltzen diren askoz ere Satznamen edo esaldi (erlatibo) toponimo gehiago Zizurko zendean Iruñerriko beste zendeetan baino, Galarkoan, Oltzakoan eta Itzakoan baino ${ }^{7}$. Hemen, bistan da, kontu egin daiteke Jimenok materialak biltzeko erabili zuen metodologia ez zela beti-batekoa izan, hots, ikerketa sakontasuna, nolabait erran, ez zela batzuetan eta besteetan bera izan, baina ez dirudi gakoa hemen den, ezagutu ere segur aski apez egondako Oltza zendeako gauzak, agiriak eta ahozko lekukotasunak hobeki ezagutzen zituzkeelako hainbeste harreman izaneztako beste zendeetakoak baino.

Eta, derradan iragaitzaz, ez da hau hemen bakarrik gertatzen den zerbait. Esaldi toponimo horiek frankok pentsatzen duten baino aise ohikoagoak dira gure toponimian (Mitxelenak urriak direla dio, 1985eko lanean), baina duten banaketa ez da bera alderdi guztietan. Adibidez, eta buruz ari naiz, ohikoak dira Lana ibarrean, Ameskoetan eta Kontrastan, baina ez hainbeste Allin ibarrean edo Gesalatzen. Cfr. Lokizko XIV. mendeko Udaradagona 'udarea, udareondoa dagoen lekua', Lur apoandaducana 'lur apoak dadukana' ausaz, hots, 'apoak dauzkan lurra'.

Ugariak dira Tolosan, baina ez dakit gauza bera erran daitekeen Gipuzkoako beste alderdiez. Bizkaian ere badira ale bakan batzuk; ez dira, ordea, beste herrialde batzuetako zenbait alderditan bezain ugariak. Arlo honetan, aitortu beharra dago, oraino anitz dago egiteko, aztertzeko, sakontzeko; hala ere, irudi luke aldeek eta desberdintasunek badirautela. Zergatik? Seguru ez dakigu, baina baduke ikuskizunik esaldi toponimoen eta elkartuen arteko lehiarekin: Oihalak ikuzten dirana (Ameskoa) vs. Lixukuzkun (< lixua ikuzten den gunea 'bokata urez garbitzen den lekua', Aezkoa), Otsoa hil zutena vs. Otsopasaketa, e.a. Hau gaztelaniazko San Martin Unxeko Donde murió el mozo > Murimozo-rekin aldera daiteke, edo Urdiaingo Laieneko haitza toponimoaren oinarrian dagoen leihoa daneko haitza-rekin (NTEM $\mathrm{X}: 100)$.

Hau erranik, ezin uka berdintasun handiak daudela, leku izenen bitartez ikus daitekeen heinean, Iruñerriko zendeen artean, eleetan, atzizkietan eta bestetan. Jimenoren liburuak argitaratuak eta berrargitaratuak daude, eta nornahiren esku.

Aranguren ez da zendea, baina bai Iruñerriko zati, eta ez dugu hain ongi ezagutzen.

7. Puntu hau garatzeko Salaberri $(2008,2014)$ eta Jimeno Jurioren Iruñerriko lanak hartu ditut oinarritzat. 
Badakigu, espero bezala, apez, batzarrekuntze, beltz, elordi, erreka, euntze (dessa itzulia, dehesa alegia: Ezpeletako eunçe burua = dessa del baron de Ezpeleta, Taxoare), harrobi, iturri, lamia, oihanko, sarri, teileria, txapardi eta beste genituela, baita Iruñ (ea) ere. Orobat aldaera palatalizatuak ohikoak zirela, hiriburuan bezala (Ermitagaña, Erripagaña): Bizkargaña, berrekailu multzokaria -di zela (Bagadibidea, Labio), e.a.

Badakigu, Euskal Herriko beste herrialdeetan bezala, euskaraz -i atxikitzen zela, ez zela irekitzen (Arçicoa vs. Arçe, Labioko etxea), toponimoetan sudurkari emea erori egiten zela, bokal artean (Labio, Taxoare, Zolia, erdaraz Labiano, Tajonar, Zolina), bokal bakuntzea gertatzen zela (Taxoare > Taxore), zenbaitetan sinkopak bazirela, menturaz azentuak eraginik ("Otra Pieca [...] en herpide [...] que afruenta [...] con el Camino»), elkarketan batzuetan bokala erortzen zela (Yrunbidea 'Iruñeko bidea', Mutiloagoiti, 1850; Iturraldea), baina beste batzuetan ez (Iturribidea), e.a.

Hauek guztiak anitzi sinplekeriak irudituko zaizkie, baina frogarik ezean, hots, toponimorik ezean ezin erranen genuke deus ere Arangurengo hizkera lekutuaren gainean, testurik oraingoz ez baita argitara atera.

\subsection{Toponimoetan generikotzat ageri diren hitzak}

Gai interesgarri bezain landugabea dugu hau. Anitzetan ez da aise erratea toponimo batean espezifikoa zer den eta generikoa zer den, baina, larri-larria, bigarrena -ra, -ren eta -ko hondarkien ondoan azaltzen dena dela erranen dugu, etxe izenetarik lekora. Hona hemen xerrenda bat:

Ardantza, ardantzea: Gauzako ardantza 'Ganuza herriko ardantzea' (Gauzaco ardanza, Ollogoien, 1711), Goitiko ardantzea (Goitico-ardancea, Akerreta, 1851).

Barga: Daliko bargaeskina (Dalico bargaesquina, Eulate-Aranaratxe, 1711).

Belagai: Beheitiko belagaia (Veitico belagaya, Azpilkueta, 1827).

Beroki: Txutxuko berokia (Suchuco beroquia, Lerga, 1613), Oihaneko berokia (Oianeco beroquia, Lareki, 1627), Ezkirozko berokia (Esquirozco beroquian [sic], Erro, 1788).

Bizkar: Sagarmendiko bizkarra (Sagarmendico bizcarra, Nagore, 1625), Iragietako elutsako bizkarra (Yraguiettaco elusaco viscarra, Lintzoain, 1780).

Eluts: Okaetako elutsa (Ocaetaco elusa, Garralda, 1800).

Ekarra 'mendi mazel harrizua': Belarreko ekarra (Aralar).

Eskina: Ubarketako eskina (Ubarquetaco esquina, Narkue, 1691).

Etxepe: Orotzaneko etxepea (Orozaneco echepea, Gerendiain Erroibar, 1796). 
Euntze: Arteko euntzea (arteco Eunçea, Iturgoien, 1559), Aldeko euntzea 'Aldea herriko euntzea' (Aldeco eunzea, Lerga, 1570).

Hegi: Angordoiko hegia (Angordoyco eguia, Nagore, 1625), Soroandiko hegia (Soro andico eguia, Galdio, 1665).

Helar: Mendiko helarra (Mendico elarra, Igari, 1680). Cfr. Zaraitzuko bereko Elarre deitura (herri + larre, itxuren arabera).

Hiri, huri: Goitiko hiria (Goiticoiria, Zabaldika, 1849). Cfr. Arabako zenbait herritako auzoak izendatzen dituen Goiko huri(a), Murukoa, kasurako.

Idoi: Ordozgo idoia (Urbasa, orain), Usarroko idoia (Ihabar, egun).

Ilartsu, ilarzu: Sapeko ilartsua, Sapeko ilarzua (Sapeco ylarsua, Sapeco ylarzua, EulateAranaratxe, 1711).

Kaskailu: Aldeko kaskailua 'Aldea herriko kaskailua' (Aldeco cascallua, Lerga, 1594).

Kino: Goitiko kinoa (Goittico quiñoa 1790, Ardaitz).

Larratz: Onazeko larratza (Onaceco larraça, Muetz, 1545).

Lepo: Urraitzolako lepoa (Urraiçolacolepoa, Lokiz, 1685).

Mendi: Aldeko mendia («la sierra llamada Aldeco mendia», Lerga, 1757).

Muno: Apingo munagaina (Biloria, 1688).

Oihan ('monte'): Iguzteko oihana, Urbeko oihana (Yguzteco oyana, Urbeco oyana, Zirauki, 1573-74), Azaroko oihana (Açaroco oyana = Monte de Açarocoa, Elo, 1659).

Oihezki: Ateko oihezkia (Ateco Oiezquia, Itzalle 1699).

Ordoki: Bagolako ordokia (Vagolaco ordoquia, Sartze, 1674), Erbiñako ordokia (Erbinaco ordoquia, Galipentzu, 1687), Maldako ordokia (Maldacordoquia, Tabar, 1730).

Ospel: Ezkirozko ospela (Ezquirozco ospela, Erro, 1788).

Pausu: Abaizko pausua 'Epaitz herrixkako pausua' (Abayzcopausua, Eslaba, 1594), Anduko pausua (Anduco pausua, Lerga, 1604).

Pentze: Xuloko pentzea (Ssuloco penzea, Luzaide, 1787).

Perra 'etxe ondoko alorra'-edo (perrana, perraña erdaraz, herrán, herrenal gaztelania 
batuan, perran- elkarketan): Behengo perra (Bengo perra, Galbarra, 1700), Sarriko perra (Sarrico perra, Aranaratxe, 1686), Sarriko perrea (Sarrico perrea, Larragoa, 1691). Araban perra, perraa, perraea, perraia, perrea eta beste ditugu (ikus bitez Martinez de Madinaren herrialde horretako liburuak).

Sakan: Mendiko sakana (Mendico sacana, Lokiz, 1685).

Saro 'saroia': Arretxeko saroa (Arrecheco saroa, Auritz, 1764).

Soro: Etxondoko soroa (Echondoco soroa, Etxabarri Allin, 1726).

Txapar (zuhamua): Arangaizko txaparrondoa (Arangayzcochaparondoa, Eslaba, 1593).

Zaldu: Galbarko zaldua (Galbarco zaldua, Narkue, 1682).

Zazu: Loperen zazua (Artaxoa).

Zelatu: Sapeko zelatua (Zapeco zelatua, Eulate-Aranaratxe, 1711). Adiera zehatza zein den ez dakigu, baina iduri du erdarazko celada-rekin lotua dagoela (La Celada, San Martín Unx, Tafalla, Zangoza, Las Celadas, Mélida, Celadeta, Oibar, Celadilla, Deikaztelu, e.a.), eta euskarazko zelata-rekin ere bai, menturaz zelatan edo zaintzan egoteko leku hauta zelako. Beste aukera bat, zelata bat egiteko leku aproposa izatea da, beheragune edo zintzur zenbait alegia; cfr. Garganta de Zelatu (egun, Ameskoabarreneko lur komunak). Etxarri Aranatzen Zelatako entrada, Zelatagaña ditugu orain.

Zorte: Beheitiko zortea (Beiticozortea, Gerendiain Erroibar, 1773). Gaztelaniaz suerte erraten zitzaien, zotz eginda epe baterako herriak uzten zituen lur puskak baitziren.

\subsection{Izen arruntzat azaldu ohi diren hitz zahar-berriak}

Hau berez ez da onomastika, baina izenen ikerketan gabiltzanean, artxibategietan eta argitaratutako agiri bildumetan, euskaraz ibili diren eta ibiltzen diren hainbat hitz agertzen zaizkigu eta, jakina, hauek ezin ditugu alde batera utzi, gure onomastika azterketan zuzenean eta ezinbestean sartzen ez badira ere. Adibideak:

Aizkolkute: "Juan Yrivarne [...] Juanis Hualde Pedro Vilbau y Juanes Aroza [...] con ocasion de saver algunas diferencias sobre los aizcolcutes llamados Sagardia y Zaquelua [...] los d[ic]hos Aizcolcutes» (Jaurrieta, 1674). Ez dakit ongi zer den -kute hori, ez baitirudi Mendikute-n dugun -kute 'zorrotza' bera denik (ikus Mitxelena, AV, 379). Lehen osagaia, Nafarroako aizkol 'arveja' dateke. Baliteke OEHn biltzen ez den aizkolerri 'aizkol landa' izenaren adierakidea-edo izatea; cfr. pataterri 'patatzea', tipulerri 'tipulatzea', e.a.

Aldabe: «Mas una pieza [...] en el termino de la aldavea de la parte de Aliaga» (Uxue, 1778). Aldabea-k, Uxuen eta bestetan, aldapak dira, maldak, baita patar xutak ere, zenbait aldiz. 
Aldazki, aldaizki: «unas pieças [...] en la aldaizquia llamada artequayça» (Uxue, 1618). Aldazki hau behin baino gehiagotan azaltzen da agirietan, eta badirudi aldatz 'aldapa'-ren eratorria dela.

Amezti: "... del lado de hacia dha casa de Granada (afrontante) con ameztia de esta dicha casa de Granada» (Luzaide, 1800). Hemen ametz zuhaitz izenaren amezti multzokari ezaguna dugu.

Artegi: «una pieca [...] con su corral y arteguia en [...] (la) endrecera llamada artecegaña» (Eslaba, 1616), «una pieza [...] en el termino de bal de Uniesa que llaman la artegui del planillo» (Oibar, 1723). Hau, garbiki, euskarazko artegi 'arditegia' dugu.

Artzara: «... teniente a casa y Arzara de Manuel Jose de Arellano» (Gorozin, 1734). Hitz hau ere artzaingoarekin dago lotua; oker ez banago Izagirrek (1994: 61) Arantzazu - Oñatin bildu zuen artxára, artxária 'pesebre de ovejas con barras para colocar la hierba' bera da, adiera desberdinxea datekeen arren, 'artegia', 'artegidun etxea' hain segur ere. Iruñerrian eta bestetan ere ongi ezaguna zen: Artzarapea (Zizur Nagusia, Jimeno Jurio, 2010: 392), Artzara, Artzarabeitikoa, Artzaragoitikoa (Espartza eta Ezkirotz, Jimeno Jurio, 2011: 18, 187), e.a.

Aska: «Mas otra en Ocaetaco elusa Mas otra en Ocaeta sobre las ascas» (Garralda, 1800). Hau Nafarroako erdaran ere franko ibiltzen den euskarazko hitza da.

Baltegi (baldegi): «otra detras del pajar o valteguia dela casa de Echandia [...] con d[ic]ho Valdeguia» (Esnotz, 1800). Baltegiak larrainetik hurbil zeuden estalpeak izaten ziren, Artazkotzen (Jimeno, 2013: 90) adibidez.

Barbide: «mas otro prado [...] en la endreçera que llaman Carrica burua [...] afrontada con camino rreal e [...] con barbidea» (Auritz, 1613). Hau hola azaltzen da, hasieran bokalik ez duela, alegia, ez da sekula *ibarbidea agertzen; bigarren osagaia bidea dela garbi dago.

Behierdisaroe: «... ha seydo e es de los seles pequennos e no de los seles grandes, que en vascuençe se llaman vehierdisaroea, que quiere dezir en castellano seles de alvergar vacas paridas», «los dichos seles que bulgarmente en vascuençe se llaman vehierdisaroeac, [ni] en el dicho sel a visto ni oydo dezir que se suelen alvergar las vacas paridas de los bustos» (Oiartzualdean, 1509, Aierbe, Irijoa eta San Miguel, 2012: 121-122). Gehienetan -h-rekin azaltzen da hitza XVI. gizaldiaren hastapen horretan.

Belauru: «... de parte del Monte afrontada con pieza de Garde y con Belauru de Garaicoa» (Lusarreta, 1788). Iduri du belar izenaren eratorri zenbait dugula hemen (cfr. belauna 'belargunea', 'larrea'). OEHn honekin zerikusi zerbait izan lezakeen belauri biltzen da.

Berro 'labakia': «... afronttan [...] al Berro de la villa [...] por la parte de Bigas con otras de Zoylo de Arbe y de Juan Simon Lizaur y Sarrea de Aldabara», "Mas un Berro [...] en Berague [...] que afronta con [...] el verro grande de la villa» (Uxue, 1708, 1778). Cfr. beste hau: «En 
los terminos y muga de las villas de Eslaba y Abayz llamados los d[ic]hos terminos el de Eslava Caldinaga y el de Abayz Piquero aren berroa» (Eslaba - Epaitz, 1648).

Betazai 'betzaina, behizaina': "... que los jurados despues de haber cumplido el año de su Jureria, el siguiente año ayan de ser betazayes y puedan prendar cualesquiera ganados en los vedados que el Concejo tiene puestos» (Hiriberri Aezkoa, 1798).

Bizkar: «... acia el zampeado de abajo desde la bizcarra de la presa» (Kaseda, 1783).

Espil: «una guerta o espilla en Zelay» (Ekala, 1700), «una perrana o espila con su borda con diferentes arboles frutiferos» (Larragoa, 1708), «Francisco Garate dueño de la Casa de Alcaiza [...] vende [...] una heredad ó espila enal» (Hiriberri Aezkoa, 1800).

Etxola: «Mas en Yralepo un sitio de Borda que con su chola esta incendiada» (Luzaide, 1801).

Flanko, planko: «una pieça [...] en [...] Ossandaberroa afrontada [...] con el rio caudal de Catoya, otra pieca llamada flancoa en las Landas de Urrutia» (Otsagabia, 1654), «... cassa de Urrutia con su guerta pegante a la dicha cassa y una zauala o flancoa que esta pegada de la una parte la Çavala o flancoa de Urrutia [...] con pieça de Corroça [...] y con Çavala de Miqueleiz» (Ezkaroze, 1665).

Gurbe: "Otra pieca en Durrundran barrena Ytten otra pieça en Durrundran donde el gurbe» (Nagore, 1625). Gurbea zuhaitz baten izena da, guk erdaraz pomo deitzen duguna.

Haltzu: «Mas otra pieza en Saraseta [...] que afronta [...] por abajo de Nagore, por una frente (sic) con una de Berradre, y por la otra la alzua» (Garralda, 1800). Badirudi haltz basoa adierazten duela.

Harmuga: «un pedaço de pieça en Amillano eRotaburua teniente con armuga del ter [min]o de Amillano» (Galdio, 1572).

Hondalan: «en el ter[mi]no de Caseda Juntto al azutte [...] para hazer viña a Ondalan» (Kaseda, 1778). Hondalan hitz hau ohikoa da gure erdaran, normalki «volver [la tierra] a ondalan» esamoldean.

Ibiki: «La toca antigua llamada Ybiquia [...] toca antigua llamada Ybiquia, un bestido de muger» (Otsagabia, 1684). Ele hau bildua da OEHn, baina erraten ez dena da XVII. menderako modaz pasatua zela, «zaharra» edo «antigoalekoa» zela.

Itandi (neurria): "Mas un campo en jurisdicion francesa de una Ytandia escasa, a las inmediaciones de la Casa de Borderrea» (Luzaide, 1801).

Larraska: «Ydem en Orobidea un Bordal con un cerrado [...] de tierra blanca feneral y larrasca que confina con las de Echetoa y Garcienea» (Azpilkueta, 1825). Larraska Baztanen 
oraino bizirik dagoen hitza da.

Lastatze: «otra pieza de una carga en lastazea de Ardanzandia», «otra pieza en lastacea de alvozcoarana» (Galipentzu, 1710, 1712). Iduri luke lasto-ren eratorria dela, 'lasto tokia' edo, baina ez da segurua. Aezkoan eta Esteribarren Lastape(a) izeneko etxeak azaltzen dira, menturaz honekin zerikusia duketenak.

Manjadera 'mainatera, gobea, ganbela': «Nuebamente embarga a mano real una porcion de alechos que existen en berrocoborda y las manchaderas que existen en la misma borda» (Luzaide, 1800).

Pentze: «Mas en Usateguieta un penze» (1800), «Mas un penze cerca de la citada Borda que afronta [...] con campo de Jaureguiberri. Mas en Osobi otro pence de dos talladores afrontante por arriva de Yaureguiberri por abaxo con pence de Echandi. Mas otro pence en Subitoa de un tallador» (1801).

Sarri: "Ytten en la ssarria de Piperatu» (Uxue, 1602), «Mas dos corrales [...] que afrontan á [...] Prado Concegil y por abajo con la Sarrea de Artabacoiz» (Uxue, 1781). Hau han-hemen errepikatzen den izena da; Nafarroan Sarria Aranatz aldeko (Sakana) eta Itzarbeibarko herri despopulatu banaren izena da, eta Araban Zuiako herri batena. Garbi dago baso edo oihan motaren bat adierazten zukeela, menturaz Oibarko Valespesa-ren antzeko zerbait (ikus Mitxelena, $A V$, 540).

Tailari (= tallador): «otra pi ${ }^{a}$ con un prado de 2 tallaris afronttante con pieza de Vidondo» (Luzaide, 1878).

Txumari (= ejecutor): «... que todos los años los chumaris (sic) o executores sean obligados de dar cuenta acabado el año dentro de dos meses» (Hiriberri Aezkoa, 1898). Ele hau aipu honetan baizik ez zait atera, eta zalantzazkotzat jo beharko, oraingoz.

Zabal: «Una cassa [...] en el barrio de Urrutia [...] y la dicha guerta con la dicha cassa que se yncluye tambien la çabala» (Otsagabia, 1654), «un linar [...] q[ue] afrontta con Huertta cerrada, y linar de d [ic]ho sr. prior, con la zabala de Martin Andres, y camino del Molino» (Uxue, 1769). Ikus flanko, planko, goraxeago.

Zerrandegi: «... [afronta] con casa de Dorreinea del de francia con casa de Zubizar por arriva con cerrandeguia de la casa de los otorgantes» (Luzaide, 1800). Egun zerrandéi 'itxitura', 'zerratua' da herri honetan.

Bestalde, burdinolekin lotutako hiztegia ere aurkitzen dugu agiri zaharretan. Hau berez dialektologia den ez dakit, baina harekin lotura baduela garbi dago, halako aldaera ager daitekeelako, bakarrik leku jakin batean ibiltzen dena edo ibiltzen zena. Adibidez, Arano eta Goizuetako XVIII. mendeko hauek aipa daitezeke (beltza nirea da):

«La composicion y uso de la dicha herreria maior la barra grande las corricas grandes Las 
agoa corricas y cabia corricas mas la suara mas otro fierro que llaman paradera delante de la fragua [...] mas unas corricas pequeñas a modo de gorbas [...] mas dos aldabarras de fierro del dicho Martinete mas dos bigurneas [...] mas dos martillos la una (sic) que llaman alzairumallua y el otra para picar menas».

«... la rueda de usso mayor con sus ondas [...] nuebas que bulgarmente tienen de nombre ylatormentateguia de la dicha rueda y usso maior y la dicha tormentateguia toda ella mobida por nezesitar de maderos nuebos por cuio motibo declaro auer entrado cinco maderos grandes nuebos para su conposion. Desta manera dos de ellos que llaman ardias y los otros ordonass y assi mismo en la antepara dos ustarriass y dos cohinas que llaman zearguilza En el tejado dos gabrios».

«... en la Antepara de la herreria de Arrambide [...] se han de poner sessenta codos de alascas Yttem ciento y veinte codos de usquerricoas Yttem ochenta codos de galdurras cumpliendo ('betez' alegia) los codos que faltaren de los maderos viejos de modo que no quede en falta de porcion de ninguna galdurra Yttem veinte pordoeas [...] Yttem nueve uztarrias nuevas las ocho sobre la antepara y Una debajo Yttem trescientos codos de mandioas nuevas y todo lo demas que faltare de las mandioas viejas que se sacaren de la d[ic]ha antepara».

«... es de largo dicha antepara sesenta codos poco mas o menos [...] se deben entender codos en quadro, como se estila en las herrerias de Goyzueta y no como en las de la Urumea beso marchantatua».

Eta Luzaideko beste hauek (XVII. mendea; beltza nirea da):

«... se a quebrado uno de los instrumentos de la dicha herreria q[ue] llaman Vnguide q[ue] sin el es inposible pueda labrar yerro».

«Joan Señant a echo y puesto en la d[ic]ha erreria diez pieças de Yerro que son [...] necesarias [...] que dichas piecas en su arte los llaman çiguillus otra pieça llamada çidermandar dos llamadas aldauar tres pusonac (prisonac?) varavalanca o barra [...] una pieça que llaman betarria [...] una pieça que llaman tobera de yerro y dos pieças llamadas ingudiac [...] e otra pieça llamada cavia». llaman ingudiac».

«... y dos pieças que llaman aldauarrac [...] otra pieça que llaman tobera [...] dos pieças que

Gatzaren ekoizpenarekin lotutako hitzak ere badira (cfr. toponimiako gatze, gazkuntze, gazlarrain), batzuk toponimo hutsak dira, baina beste batzuk ez (Getze Ibargoiti, XVII. mendekoak gehienak; beltza nirea da):

«Mas medio quarto de poço de haçer Sal que tienen en La parte llamada Gueçe artea Yten el poco llamado buçu nausia con ocho heras de hacer sal y una totocha de tener agua [...] mas otra her[r]ada de agua que tienen en el poco que llaman Buchucoa».

«Y dos totochas assi vien salineras [...] en [...] la endreçera llamada gueçeartea». 
«una porsion de media herrada de agua [...] En el pozo llamado buchucoa En Usateguia auna con sus heras y totochas pertenezientes a ella».

«... medio quarto de pozo [...] en Guezeartea en el pozo llamado buzu andurcoa».

«... venden [...] un medio quarto de pozo salinero con siete heras y dos totochas y una totosmutua salineras [...] que el dho medio quarto de pozo es en el pozo llamado buçunausia [...] y las d[ic] has siete heras dos totochas y totosmutua estan contiguas las unas de las otras».

«... el otro medio quarto en el poço de Andurcoa tambien con sus heras de hacer sal».

«... en los pocos llamados buçubeçin y buchucoa y Usateguia».

"dos medios quartos de poços salineros con doçe heras dos tochochas (sic) y dos totosmutuas [...] sitas [...] en la endrecera llamada gueçe artea que el un medio quarto de poço es en el poco llamado buçu nagusia y el otro medio [...] es en el poço llamado tornua».

«los poços llamados Buçunagusia y Tornua».

«... en el dicho Lugar de Salinas en los pozos llamados buen bacin buchucoa y Usateguia».

«... en el pozo llamado Andurcoa en Gueceartea».

«... en el pozo llamado Buzu Naussia con siete heras y dos totochas».

«Mas otro me quarto de poço en el poço llamado Ubacoa».

«... mas un quarto de poço con sus heras y totochas del pertenecientes en el poço llamado bucubecin Mas otro me quarto de poço en el poço llamado Andurcoa».

«... pozo salinero llamado hubacoa que es en la endrezera llamada guezeartea».

«... en el Pozo de Bucu Nausi y el otro medio Quarto, en el Pozo llamado Chornuqua [...] con su totosa».

Laburtuz eta bukatzeko, onomastikak dialektologiari munta handiko ekarpenak egin diezazkiokeela uste dugu, lehenbizi zenbait toponimo nagusitan kausitzen ditugun atzizki eta bukaerek populazioguneak sortu zirenean Euskal Herrian edo Euskal Herriko alderdi batean zeuden jende mugimenduen, izen moden eta besteren berri ematen digulako. Orobat, herri izen batzuek (Ehari, Elheni villa, Obekuri) duten egitura zentzu berean mintzo zaigu, hots, deizioek era batera edo bestera antolatzeko zeuden joeren gaineko informazioa ematen digute. Hemen eskualde batekoak diren atzizki ereduak (Gernika, Sondika, Zúñiga) eta hedatuagoak direnak (Beraskoain eta Beraskoitz batik bat) bereiz daitezke, nahiz oraindik lan franko dagoen egiteko, puntu anitz argitzeko eta zehazteko (Baliarrain, Xemein...), konparaziorako atzizki, bukaera eta eredu bakoitzaren aspaldikotasuna edo adina. 
Bigarren, onomastika datuek euskara lekutu den Euskal Herriko eremu zabal bateko hizkera neurri batean ezagutzeko aukera ematen digute, bestela, testurik ezean, ez baikenuke gauzen berri jakiteko biderik. Behin baino gehiagotan erran denez, izenak ez dira erakustun hoberenak, joskera, aditz kontuak, esamoldeak eta abar onomastika datuen bitartez gehiengehienetan ezin azter daitezkeelako, baina, nolanahi ere, toponimoek eta antroponimoek ematen dizkiguten argitasunak ez dira inola ere gutiesteko modukoak. Erran bezala, gehienak morfologia (eratorpena) eta hiztegi mailakoak dira, baina deklinabidearen arloko zehaztasun zenbait ere erdiets daitezke (inesibo, adlatibo, genitibo eta leku genitiboaren ingurukoak, batik bat), eta fonetika kontuak ere iker daitezke, neurri batean (palatalizazioa, adibidez). Azentuatze era zahar eta berriez ere zerbaixka ikas daiteke, kasurik onenetan.

Hiztegiari doakionez, toponimoen generikoetan dugun altxorra oraino ongi aztertzeko dago, eta artxibategi lanetan onimo xerka gabiltzanean azaltzen zaizkigun zenbait arlotako eleak ere interesgarri suerta daitezke, euskal lexikoa aberastu eta osatzeko tenorean. Errate baterako, eta ikusi dugun bezala, burdinolen eta gazkintzaren arloetako hainbat hitz ateratzen zaizkigu. 


\section{Bibliografia}

Aierbe, M.R., Irijoa, I. eta San Miguel, A., 2012, Documentación medieval del archivo de Oiartzun. II. Pleito de los ferrones (1218-1514), Donostia: Eusko Ikaskuntza, «Fuentes documentales medievales del País Vasco» 145.

Camino, I., 2009, Dialektologiatik euskalkietara tradizioan gaindi, Donostia: Elkar.

2011, «Ekialdeko euskararen iraganaz», in: Epelde, I. (arg.), Euskal Dialektologia: Lehena eta Oraina, 87-153, Bilbo: Euskal Herriko Unibertsitatea, ASJU-ren gehigarriak, 69.

Camino, J., 2008, Herria maitez, Eliza maitez, Getaria Lapurdi.

Carrasco, J., 1973, La Población de Navarra en el siglo XIV, Iruñea: Nafarroako Unibertsitatea.

Egurtzegi, A., 2014, Towards a phonetically grounded diachronic phonology of Basque, doktore tesi argitaragabea; hemen eskura daiteke: [https://www.academia.edu].

Fernández de Palomares, V., 2007, Valdegovía y su entorno. Páginas de historia y documentación, Gasteiz: Arabako Foru Aldundia.

González Salazar, J.A., 1986, Toponimia de la Montaña alavesa, Gasteiz: Arabako Foru Aldundia, «Cuadernos de Toponimia» 2.

Grandes, F., 1929, «Algunas palabras euskéricas», Euzkal-Esnalea 19, 123-125.

Izagirre, K., 1967, «Altsasuko euskeraren gai batzuk», ASJU 1, 45-97.

1994, El Vocabulario vasco de Aránzazu-Oñate y zonas colindantes, Villasante, L. (arg.), Donostia - Oñati: Gipuzkoako Aldundia eta Oñatiko Udala, ASJU-ren gehigarriak, 7.

Jimeno Jurio, J.M., 2010, Toponimia navarra III. Cuenca de Pamplona. Cendea de Zizur, Iruñea: Zizurko Udala - Udalbide - Pamiela - Euskara Kultur Elkargoa, «Obras completas de José $\mathrm{M}^{\mathrm{a}}$ Jimeno Jurío» 42.

,2011, Toponimia navarra IV. Cuenca de Pamplona. Cendea de Galar, Iruñea: Galarko Udala - Udalbide - Pamiela - Euskara Kultur Elkargoa, «Obras completas de José Ma Jimeno Jurío» 43.

, 2013, Toponimia navarra V. Cuenca de Pamplona. Cendea de Oltza, Iruñea: Udalbide Pamiela - Euskara Kultur Elkargoa, «Obras Completas de José Mª Jimeno Jurío» 44.

2014, Toponimia navarra VI. Cuenca de Pamplona. Cendea de Itza, Iruñea: Udalbide Pamiela - Euskara Kultur Elkargoa, «Obras Completas de José Mª Jimeno Jurío» 45.

(zuz.), 1992, Nafarroako Toponimia eta Mapagintza / Toponimia y Cartografía de Navarra.

Bakaiku - Urdiain - Iturmendi (NTEM), Iruñea: Nafarroako Gobernua, 10.

Jimeno Jurio, J.M. eta Salaberri, P., 1998, Artajona. Toponimia Vasca / Artaxoa. Euskal Toponimia, Lizarra: Altaffaylla Kultur Taldea - Nafarroako Gobernua - Sociedad de Corralizas y Electra de Artajona.

2006, Toponimia navarra VIII. Cuenca de Pamplona. Pamplona/Iruña, Iruñea: Udalbide 
- Pamiela - Euskara Kultur Elkargoa, «Obras completas de José Mª Jimeno Jurío» 47. Euskaltzaindiak Bilbon 1994an ( Onomasticon Vasconiae» 12) egindako Toponimia de la Cuenca de Pamplona. Pamplona/Iruña argitaraldiaren berrargitalpen osatua da.

Kamino, P. eta Salaberri, P., 2007: Luzaideko Euskararen Hiztegia, Bilbo: Nafarroako Gobernua - Euskaltzaindia, «Mendaur» 3. , Luzaideko euskararen deskribapena, lan argitaragabea. Luzaideko etxeen izenak, lan argitaragabea.

Lakarra, J.A., 2009, « *h3 > h1, *h2 > h1 eta horiei datxezkien zenbait fenomenoz», Lapurdum $13,211-231$.

2011, «Gogoetak euskal dialektologia diakronikoaz: Euskara Batu Zaharra berreraiki beharraz eta haren banaketaren ikerketaz», in: Epelde, I. (arg.), Euskal Dialektologia: Lehena eta Oraina, 155-241, Bilbo: Euskal Herriko Unibertsitatea, ASJU-ren gehigarriak, 69 .

Líbano, A., 2000, «Toponimia menor: onomástica comercial», in: Gorrotxategi, M. eta Knörr, H. (arg.), Actas de las II Jornadas de Onomástica. Orduña, Septiembre de 1987 / II. Onomastika Jardunaldien Agiriak. Urduña, 1987ko Iraila, 435-445, Bilbo: Euskaltzaindia, «Onomasticon Vasconiae» 17.

Lopez de Gereñu, G., 1983, «Toponimia de Contrasta», Piarres Lafitte-ri omenaldia. Homenaje a Pierre Lafitte. Hommage à Pierre Lafitte, 415-423, Bilbo: Euskaltzaindia, «Iker» 2.

,1989, Toponimia Alavesa seguido de Mortuorios y Despoblados y Pueblos Alaveses, Bilbo: Euskaltzaindia, «Onomasticon Vasconiae» 5.

Maiora, Fdo., 2011, Reino de Navarra. Euskera. Injurias, coplas, frases, Villatuerta.

Manterola, J., 2015, Euskararen morfologia historikorako: artikuluak eta erakusleak / Towards a history of Basque morphology: articles and demonstratives, doktore tesi argitaragabea.

Mitxelena, K., 1971, «Toponimia, léxico y gramática», FLV 9, 241-267.

,1976, «Onomástica y Población en el antiguo reino de Navarra: la documentación de San Millán”, in: XII Semana de Estudios Medievales 1974, 49-71, Iruñea: Institución Príncipe de Viana.

, 1985, "Algunos nombres de Contrasta", ASJU 19.2, 595-602.

1997, Apellidos Vascos (AV), Donostia: Txertoa, bosgarren argitaraldia.

Pozuelo, F., 2001, Documentación Municipal de la Cuadrilla de Salvatierra: Municipios de Asparrena y Zalduondo (1332-1520), Donostia: Eusko Ikaskuntza, «Fuentes documentales medievales del País Vasco» 109.

Salaberri, P., 1991, «Do.i atzizkiaren ondorengoak Nafarroan», FLV 57, 33-53.

, 1994, Eslaba aldeko euskararen azterketa toponimiaren bidez, Bilbo: Euskaltzaindia, «Onomasticon Vasconiae» 11.

,1998, «Arabako mugako nafar hizkeren inguruan», in: Camino, I. (arg.), Nafarroako hizkerak, 49-87, Donostia: Udako Euskal Unibertsitatea. 
2004, «Artatzako euskal testua. Transkripzioa eta hizkuntza azterketa», FLV 97, 537554.

2008, «Satznamen direlakoen inguruan. Erlatibozko perpausetan jatorri duten toponimoak aztergai», in: Artiagoitia, X. eta Lakarra, J.A. (arg.), Gramatika Jaietan. Patxi Goenagaren Omenez, 724-741, Bilbo: Euskal Herriko Unibertsitatea, «Julio Urkixo» Euskal Filologi Mintegiaren Urtekariaren Gehigarriak, 51.

2014, «On the relation between toponymy and syntax: Basque and Spanish place names based on relative clauses», in: Tort, J. eta Montagut, M. (arg.), Names in daily life. Proceedings of the XXIV ICOS International Congress of Onomastic Sciences, 14091419, Barcelona: Generalitat de Catalunya, Departament de Cultura.

2015a, «Murillo el Fruto: XIV. gizaldiko agiria», FLV 120, 407-432.

2015b, Araba/Álava. Los nombres de nuestros pueblos, Bilbo: Euskaltzaindia - Arabako Foru Aldundia, «Izenak Bilduma» 5.

Santano, J., 2000, «Apoteconimia de Vitoria: un estudio de onomástica comercial», in: Gorrotxategi, M. eta Knörr, H. (arg.), Actas de las II Jornadas de Onomástica. Orduña, Septiembre de 1987 / II. Onomastika Jardunaldien Agiriak. Urduña, 1987ko Iraila, 331346, Bilbo: Euskaltzaindia, «Onomasticon Vasconiae» 17.

Santazilia, E., 2015, «Garai arkaikoko euskara nafarraren lekukotasun berriak: gehiketak eta zuzenketak F. Maioraren liburuari», FLV 119, 109-146.

Satrustegi, J.M., 1965-66, «Las casas de Valcarlos», Anuario de Eusko-Folklore 21, 13-34. Lan honek berriz Revista de Dialectología y Tradiciones Populares-en ikusi zuen argia, 1968an (24.1-2, 121-145).

Ubieto, Ag., 1978, Cartularios (I, II y III) de Santo Domingo de la Calzada, Zaragoza, «Textos Medievales» 56.

Zaldua, L.M., 2015, «Saroi entitate geografikoaren banaketa, esanahia eta etorkia toponimiaren argitan», FLV 119, 175-221.

Zuazo, K., 2010, Sakanako euskara. Burundako hizkera, Iruñea - Bilbo: Nafarroako Gobernua Euskaltzaindia, «Mendaur» 8.

2012, Arabako Euskara, Donostia: Elkar. 